تأثير برنامج تدريبى بإستخدام تمرينات S.A.Q على تحسين بعض المتغيرات البذنية

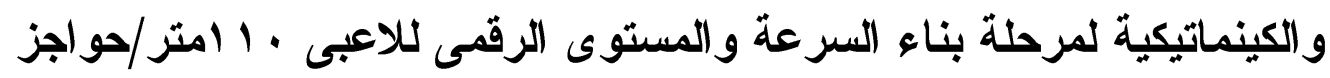

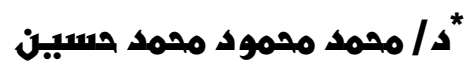

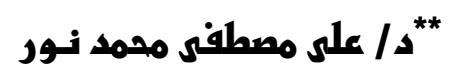

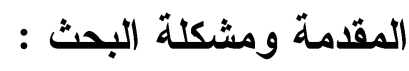

تعتبر الرياضة مجالا علميا ذو طبيعة خاصة ينسابق فيه المتخصصين كل فى مجــال

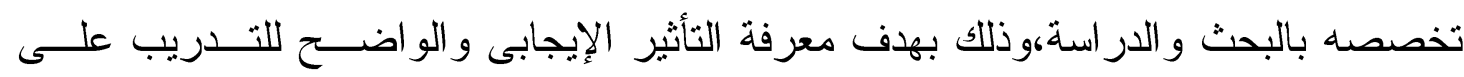
مختلف أجهزة الجسم فى الرياضات المختلفة من خلال الأبحاث و الدراسات سواء ولاء المعملية أو الو النطبيقية التى تساهم وبشكل كبير فى حل المشكلات المتعلقة بالرياضة.

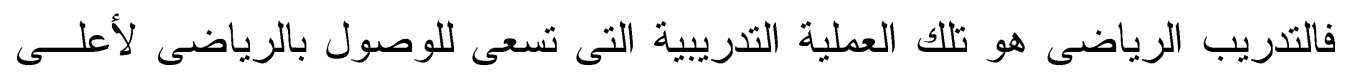

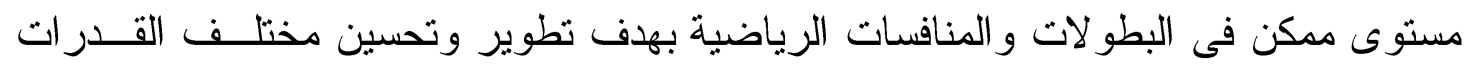

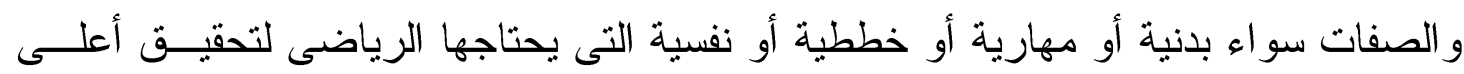
مستوى ممكن من الإنجاز فى الأنشطة الرياضية المختلفة.(r:OV)

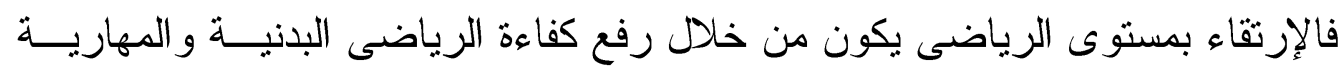

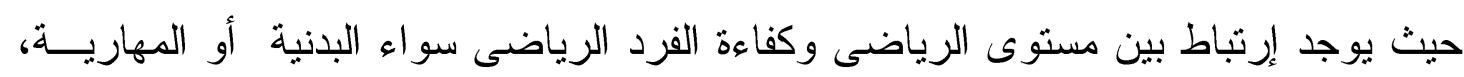

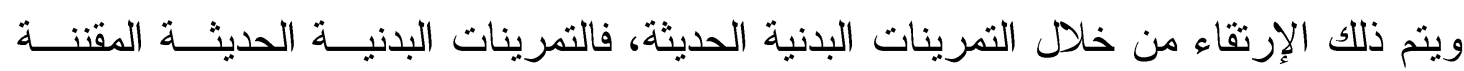

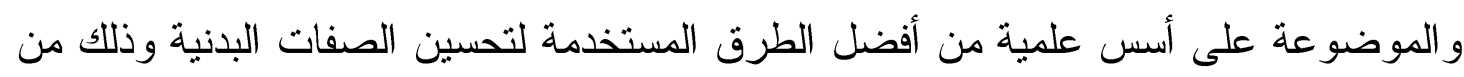

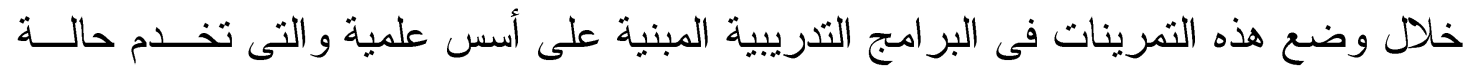

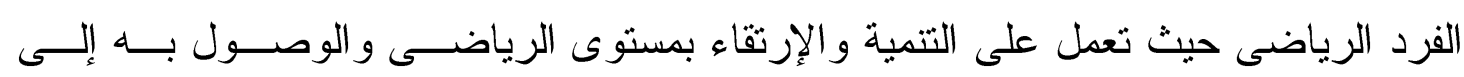

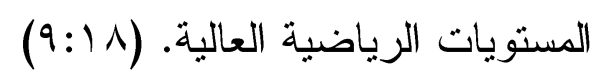
وتعتبر تمرينات (S.A.Q) من التمرينات الحديثة التى ظهرت في الأونـــة الأخبــرة

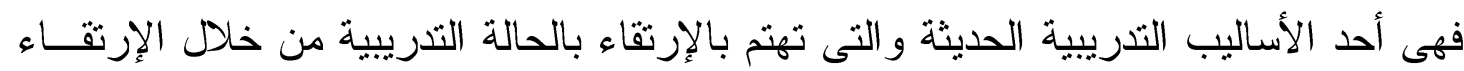

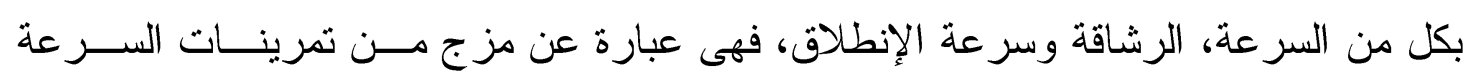

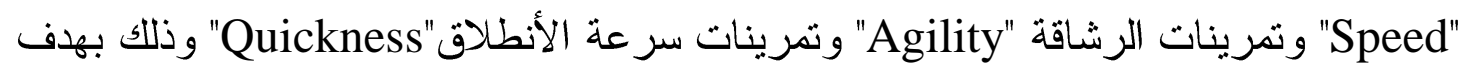

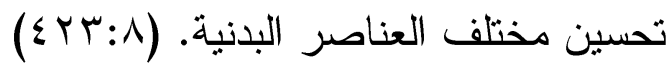

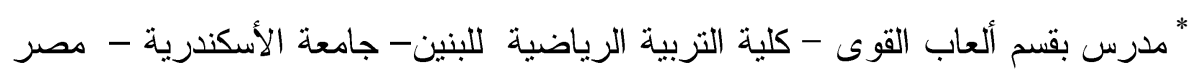

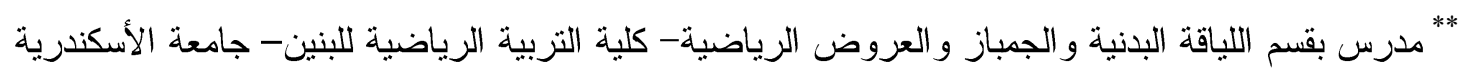


وتستخدم هذه التمرينات فى العديد من الألعاب الرياضية مثل كرة القدم و السلة و التتس

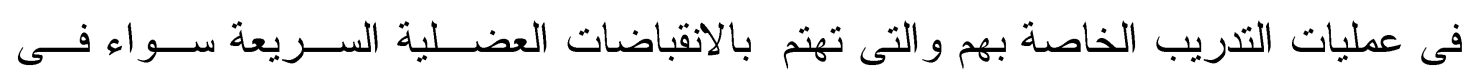

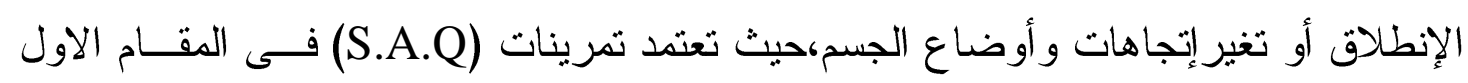

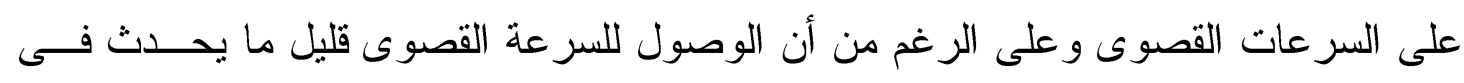

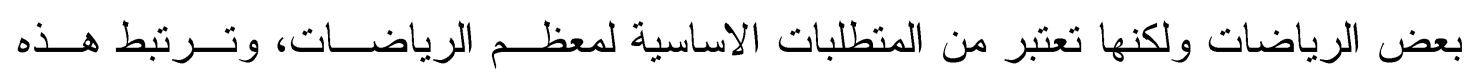

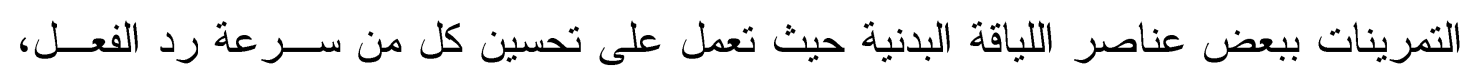

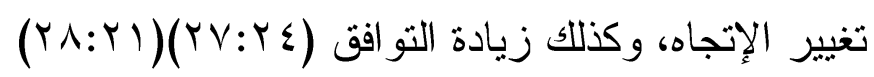

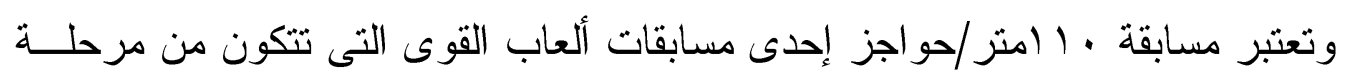

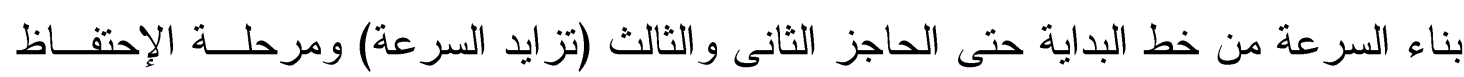

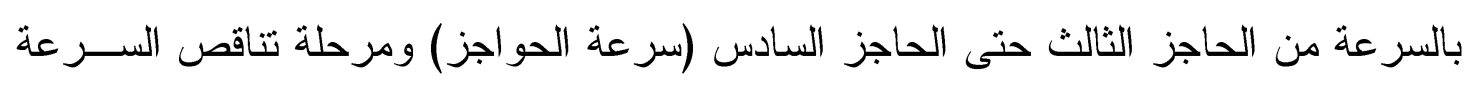

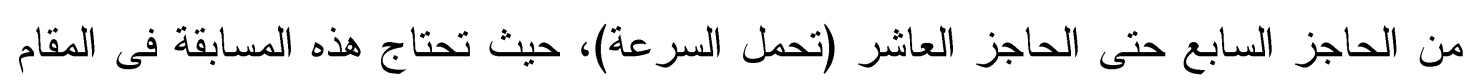

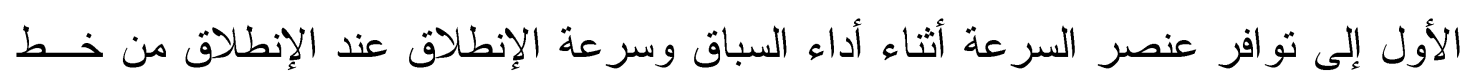

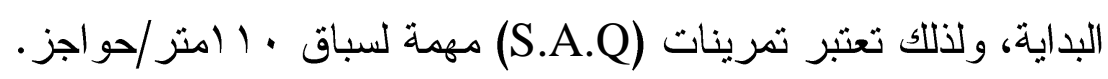

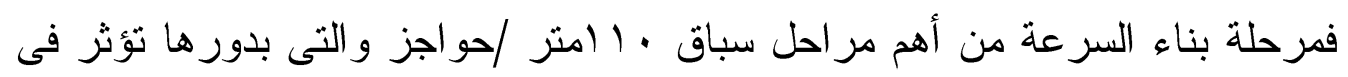

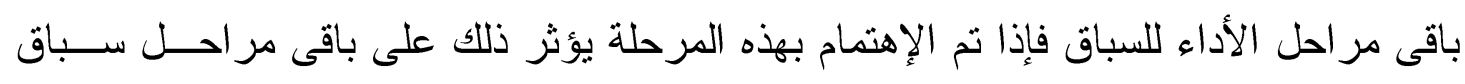

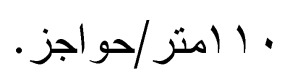

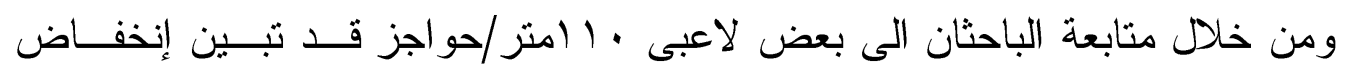

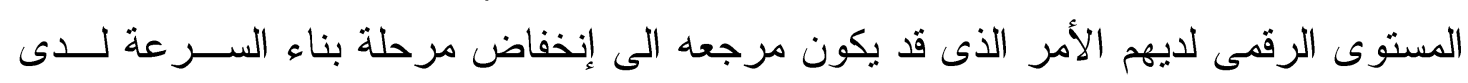

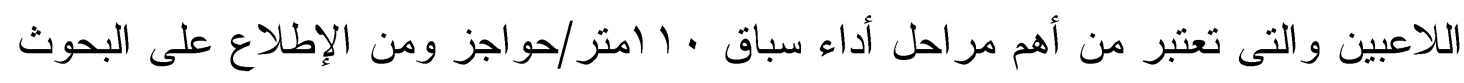

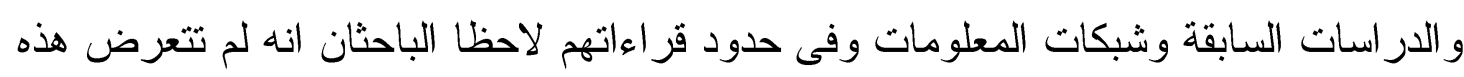

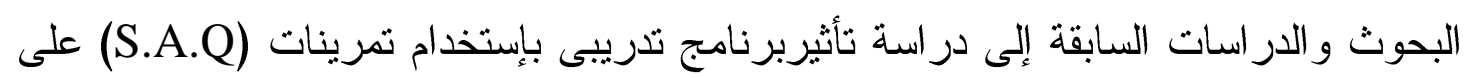

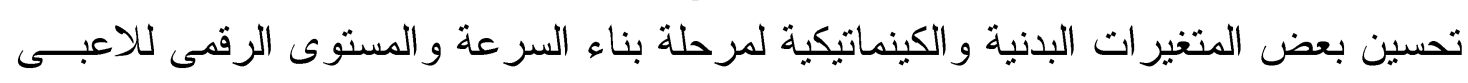

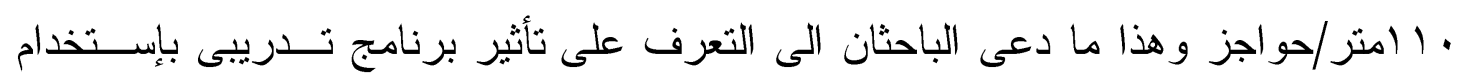

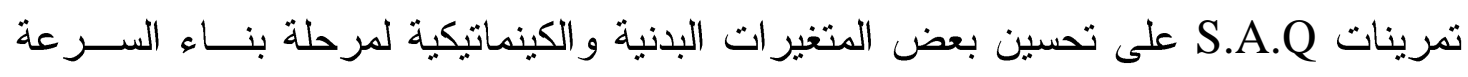

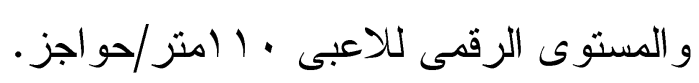

هدف البحث:

حدد الباحثان الهيف العام من هذه الدراسة فى محاولة التعرف على " تأثير برنــامج

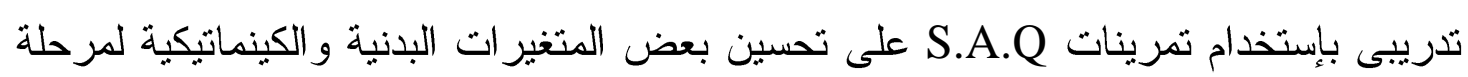

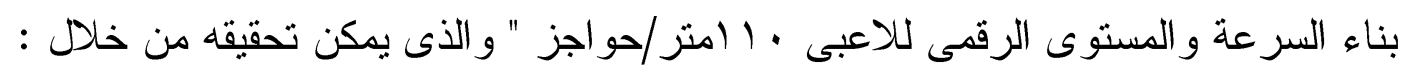


1- التعرف على دلالة الفروق بين القياس القبلى و البعدى للمجموعة التجريبية علي بعـض التض

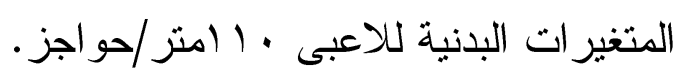

r- التعرف على دلالة الفروق بين القياس القبلى والبعدى للمجموعة التجريبية علي بعـض التص

المتغير ات الكينماتيكية لمرحلة بناء السرعة للاعبى · ل المثر/حو اجز .

ب- التعرف على دلالة الفروق بين القياس القبلى و البعدى للمجموعة التجريبية علي المستوى

$$
\text { فروض البحث : الرقمى للاعبى · 1 امنر/حو اجز. }
$$

1- توجد فروق ذات دالة إحصائية بين القياس القبلى و البعدى للمجموعة التجريبية فى بعض التص

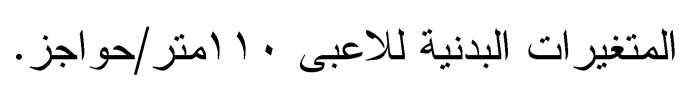

ץ- توجد فروق ذات دالة إحصائية بين القياس القبلى و البعدى للمجموعة التجريبية فى بعض

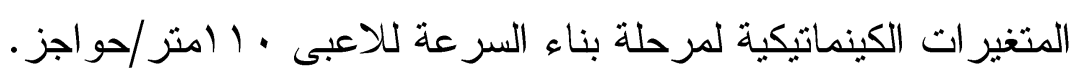

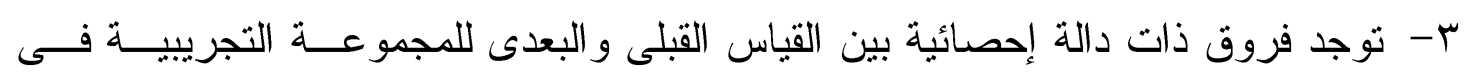

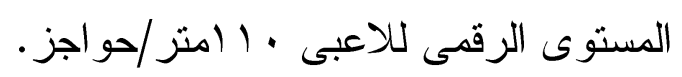

$$
\text { منهر اعات البحث : }
$$

استخدم الباحثان المنهج التجريبى ذو التصميم التجريبى للمجموعة الواحدة بالقياسات

القبلية البعدية وذلك لملائمته لطبيعة وهدف البحث.

\begin{tabular}{|c|c|c|}
\hline \multicolumn{2}{|c|}{ الفتزرة الزمنـية } & \multirow{2}{*}{ الإجراءات } \\
\hline إلى & jo & \\
\hline 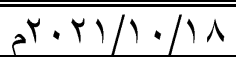 & PY.rY/1/10 & تم إجراء البحث \\
\hline$e^{Y \cdot Y} / / / / T$ & P.rY/1/10 & القياسات القبلية \\
\hline$\left.P^{r} \cdot r\right) / 1 \cdot / 1 \varepsilon$ & Pr. YI/^/rI & الدر اسة الأساسية \\
\hline$a^{Y} \cdot r / 1 \cdot / 11$ & $a r+r I / 1 \cdot / I V$ & القياسات البعدية \\
\hline
\end{tabular}

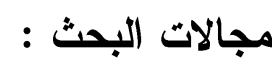

المجال الزمنى: قام الباحثان بتتفيذ إجراءات الدراسة خلال الموسم التذريبي وكانت على النحو

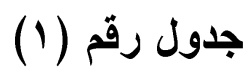

التالى التوزيع الزمني لإجراءات روم البحث

المجال المكاني: قام الباحثان بتنفيذ البرنامج التجريبي في ميدان ومضمار ألعاب القوى بنادى سموحة الرباضىى. 
المجال البشري: لاعبى · ا (متر/حواجز بناديى الإسكندرية الرياضــي سـبورتتج، ونـادي سموحة الرياضي. عينة البحث : مهو :

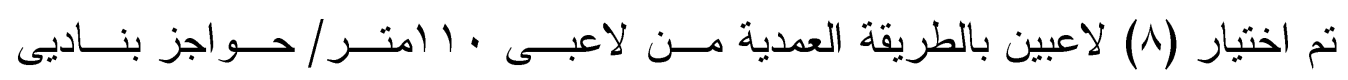

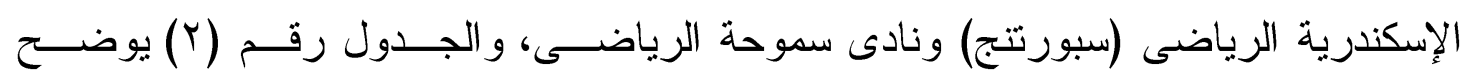

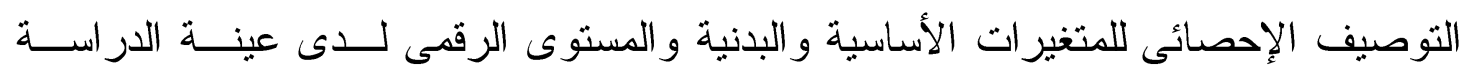
الأساسية قبل التجربة

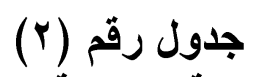

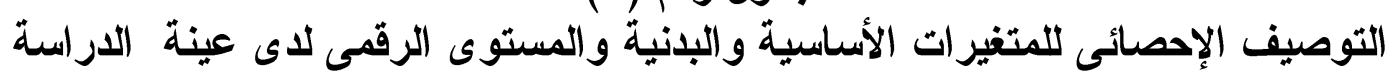
الأساسية قبل التجربة ن

\begin{tabular}{|c|c|c|c|c|c|c|c|c|}
\hline معامل & 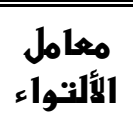 & المعيارى الاف & المستوسط & القياسة & \multicolumn{4}{|c|}{ 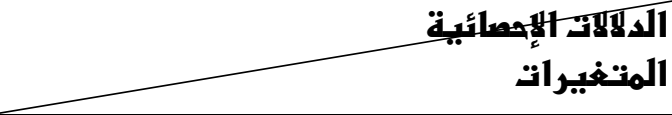 } \\
\hline 0.15 & -0.30 & 1.25 & 20.13 & (سنة) & \multicolumn{3}{|r|}{ السن } & $\overline{3}$ \\
\hline-0.92 & -0.15 & 5.21 & 181.38 & (سم) & \multicolumn{3}{|r|}{ الطول } & $\frac{5}{1}$ \\
\hline-1.81 & -0.11 & 5.83 & 74.63 & (كجم) & \multicolumn{3}{|r|}{ الوزن } & $\overline{3}$ \\
\hline-1.39 & -0.28 & 0.83 & 8.13 & (سنة) & \multicolumn{3}{|c|}{ العمر التدريبى } & 承: \\
\hline-1.37 & 0.69 & 17.06 & 108.75 & (كجم) & \multirow{2}{*}{\multicolumn{2}{|c|}{ 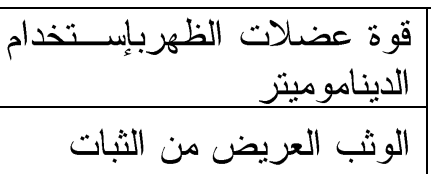 }} & \multirow{6}{*}{ 初 } & \multirow{10}{*}{ 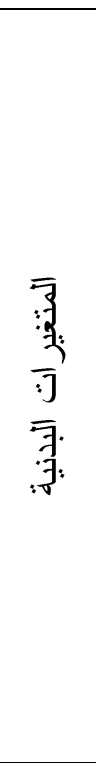 } \\
\hline 3.36 & 1.45 & 11.65 & 225.00 & (سم) & & & & \\
\hline 1.65 & -1.24 & 0.39 & 13.80 & (متر) & مسافة & اختبــــــار 7 & & \\
\hline-0.50 & 0.81 & 0.06 & 3.01 & $(ث)$ & زمن & حجــــلات & & \\
\hline 0.18 & -0.77 & 0.40 & 13.85 & (متز ) & مسافة & وحســـــاب & & \\
\hline 1.40 & 1.27 & 0.14 & 3.03 & (ث) & 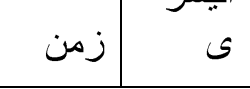 & 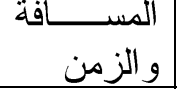 & & \\
\hline-1.14 & 0.46 & 0.24 & 4.36 & (ث) & تــر مـن البــدء & | عــــــ 30 ـ & \multirow[t]{2}{*}{ السر عة } & \\
\hline-1.10 & 0.37 & 0.27 & 3.53 & (ث) & من البدء الطائر & 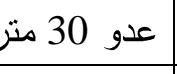 & & \\
\hline-1.74 & -0.26 & 1.60 & 6.38 & (سم) & \multicolumn{2}{|c|}{ ثنى الجذع من الوقوف } & المرونة & \\
\hline-0.02 & -0.61 & 1.28 & 25.25 & (درجة & \multicolumn{2}{|c|}{ الإنبطاح المائل من الوقــوف } & الرشاقة & \\
\hline 2.35 & 1.55 & 0.70 & 16.35 & $(ث)$ & \multicolumn{4}{|c|}{ المستوى الرقمى للاعبى · ل11 متر/حو اجز } \\
\hline
\end{tabular}

يتضح من الجدول رقم (Y) الخاص باللتوصيف الإحصــائى للمتغيـر ات الأساســية

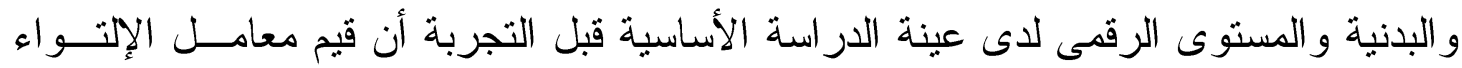


لجميع المتغيرات جاءت قريبة من الصفر حيث إنحصرت قيم معامل الالتو اء ما بين(-ــ ـ ـ ( )

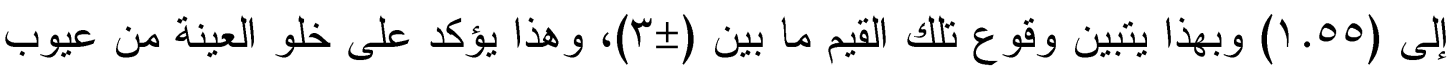
التوزيعات غير الاعتدالية.

الأدوات والأجززة المستخدمة في البحث : الأنة - جهاز (الرستامير) (لقياس الطول).

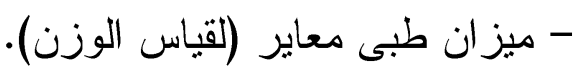

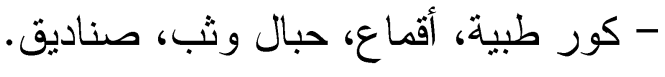

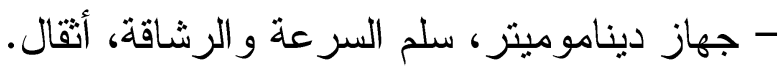
- أستلك مطاط، حو اجز ، علامات. - برنامج dart fish للتحليل الحركى. - شريط قياس، جير ، مسطرة. - ساعة إيقاف 100/1. - مكعبات بدء، صافرة.

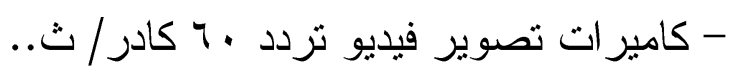

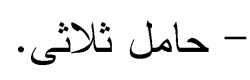

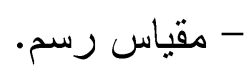

القياسات والإختبار رات المستخدمة للبحث :

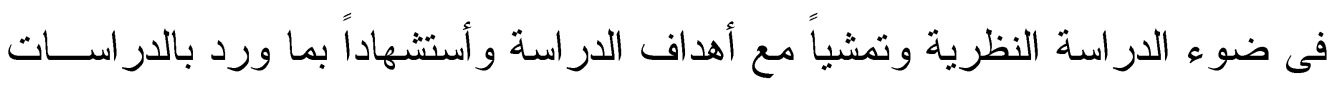

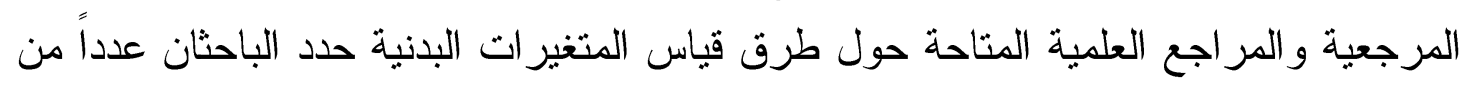

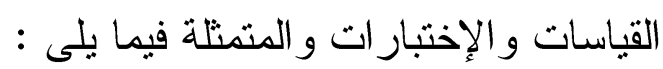

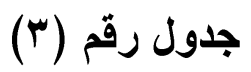

القياسات والإختبار ات المستخدمة في البحث

\begin{tabular}{|c|c|c|c|c|c|}
\hline المرقمع & 1إِفتبارات & | القياسات & المرقم & الإضنتبارات & القباسات \\
\hline \multirow{2}{*}{17} & المندف 30 متز مــن البـــــ & \multirow{2}{*}{ 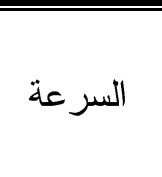 } & \multirow{2}{*}{10} & \multicolumn{2}{|c|}{ قياس الطول بإستخدام جهاز (الرستامير) } \\
\hline & الطدوئر •ب متر من البـــــ & & & \multicolumn{2}{|c|}{ قياس الوزن باستخدام ميزان طبى معاير } \\
\hline $1 \varepsilon$ & 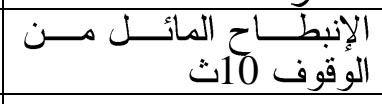 & 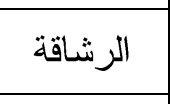 & 17 & قالديناموميترلات الظهربإستخدام & \multirow{3}{*}{ 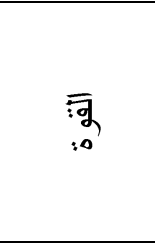 } \\
\hline \multirow[b]{2}{*}{ ir } & \multirow[b]{2}{*}{ ثنى الجذع من الوقوف } & \multirow[b]{2}{*}{ 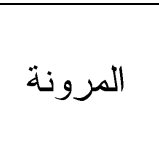 } & 17.1 & الوثب العريض من الثبات & \\
\hline & & & $1 \varepsilon$ & المنتبارة و الزمنلات وحســاب & \\
\hline & \multicolumn{2}{|c|}{ مجالة أسيوط لعلوم وفنون التربية الرياضية } & & & \\
\hline
\end{tabular}




\section{Y 99}

و التى تم تحديد معاملاتها العلمية(الصدق -الثبات) فى العديد من المراجـع و البحــوث

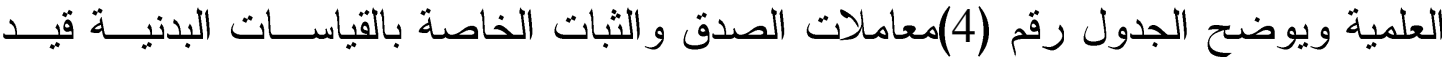

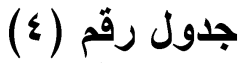
البح.:

\section{معاملات الصدق والثبات الخاصة بالقياسات البدنية قيد البحث}

\begin{tabular}{|c|c|c|c|c|c|c|}
\hline رقمم رجم & الثباتات & نوع الثبات & معامل & نوع الصدة & \multicolumn{2}{|c|}{ القياسات البدنية } \\
\hline 10 & $\cdot .9 V$ & التطبيق & $\cdot \wedge 7$ & الطرفية & قالديناموميتز عضلات الظهربإســتخدام & \multirow{3}{*}{ 司 } \\
\hline$\varepsilon$ &.$\wedge 7$ & التطبيق التــق و إعـــــادة & $\cdot . \wedge 9$ & الطقارنة & الوثب العريض من الثبات & \\
\hline 0 & $\cdot .19$ & التطبيق & -.91 & الطرفية & المسافة و الزمن حجـلات وحســـاب & \\
\hline 1. & $.9 \mathrm{~V}$ & التطبيق التطـق و إعـــــادة &.$V 7$ & التمايز & المنـخفض 30 متــر مــن البـــدء & \multirow{2}{*}{ السر عة } \\
\hline$\varepsilon$ &. Vo & التطبيق التــق و إعـــــادة & .911 & المقارنة المبة & عدو • • متر من البدء الطائر & \\
\hline$\varepsilon$ &. .19 & التطبيق التــق و إعــــادة & .91 & المرفية المقارنة & الإنبطاح المائل من الوقــوف & الرشاقة \\
\hline$\varepsilon$ & $\cdot \wedge$. & التطبيق & $.9 \leq$ & المقارنة & ثنى الجذع من الوقوف & المرونة \\
\hline
\end{tabular}

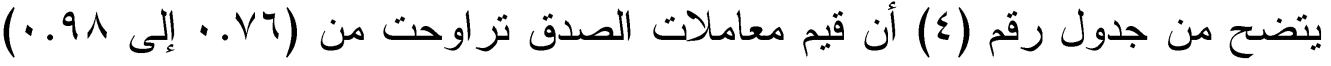

$$
\begin{aligned}
& \text { وترواحت قيم معامل الثبات من (0 V. • إلى V9. • ). } \\
& \text { إجراءات التصوير: }
\end{aligned}
$$

تم إستخدام ب كامير ات تردد ، ج كادر /ثانية،كل كامير ا مثبتة على حامل ثلاثى خارج المضمار وعمودية على الحواجز الثلاث الأولى لمرحلة بناء السرعة للسباق. - مجال كل كامير | 1 ( متر (0.0 متر قبل الحاجز، 0.0 متر بعد الحاجز). - مسافة التداخل بين الكامير ات 1 ــ ا متر . - بعد كل كامير ا عن الحاجز • ـ.0 (متر . - إرتفاع الكامير ات · r . . مثر. - تم تصوير مقياس الرسم أمام كل كامير ا وفى منتصف مجال الحركة. 
YV.

- أدى كل منسابق سباق • ا (متز/حواجز طبقا للقو اعد القانونية للإتحاد الدولى لألعاب القوى من حيث (المسافات- إرتفاع الحو اجز و عددها) وتم تسجيل زمن السباق بالتوقيت اليـدوى لأقرب ا ... ث ونم بدء السباق من مكعبات البدء و إستخدام طلقة البداية.

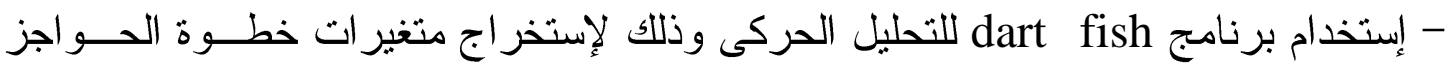
الثلاث الأولى لمرحلة بناء السرعة للسباق.

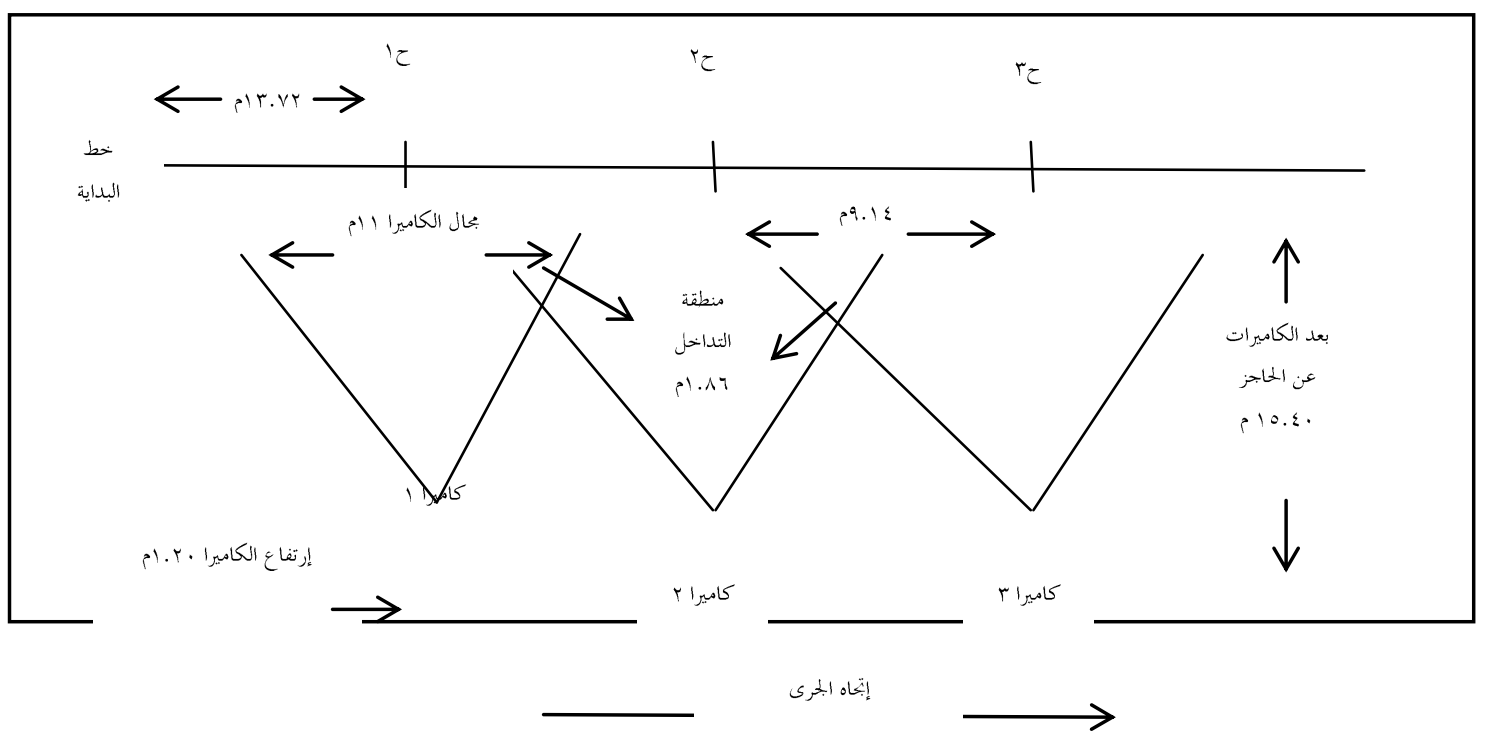

شكل رقم ( ) يوضح أماكن وضع الكاميرا أثناء تصوير الأداء المهارى لمرحلة بناء السرعة للاعبى · م11 متر/حواجز

بناء البرنامج التدريبي المقترح:

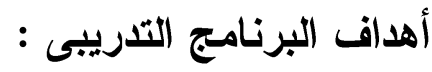

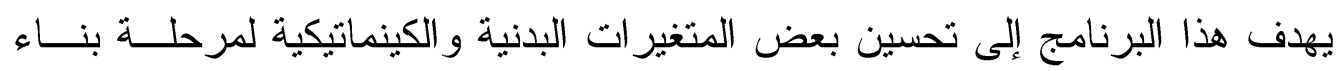

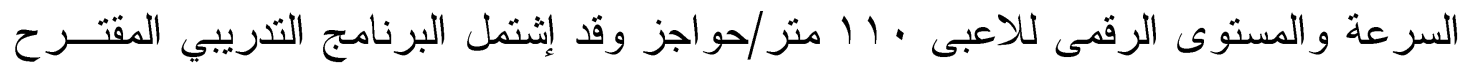
علي مجموعة من التمرينات لكل من الإحماء و المرونة و الإطالة والاعداد البدنى و التطبيقى

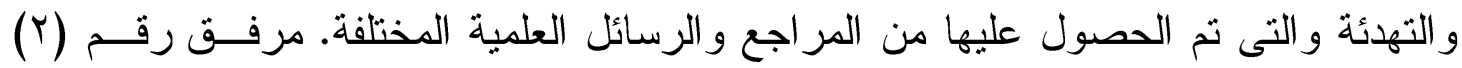

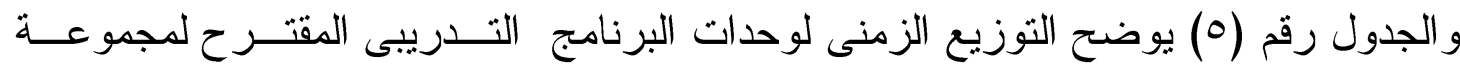
البحث. 


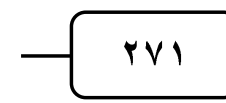

\section{جدول رقم (0)}

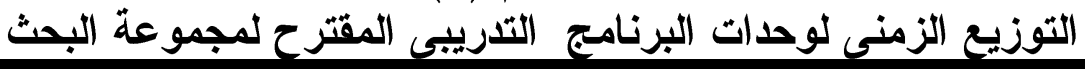

\begin{tabular}{|c|c|c|c|c|c|c|c|}
\hline \multicolumn{6}{|c|}{ أجزاء الوحدة التدر يبية } & \multirow[b]{4}{*}{ الوحدة التندربيبة المستفدة فية } & $\overline{7}$ \\
\hline الجزء الفتامي & \multicolumn{3}{|c|}{ الجزء الأساسى } & \multicolumn{2}{|c|}{ البزء التمهيدى } & & \\
\hline \multirow[b]{2}{*}{ التهدئة } & تطبيقى & الجزء الج & & & & & \\
\hline & الرستوى الرقنى & $\begin{array}{l}\text { تمرينات } \\
\text { S.A.Q }\end{array}$ & البدنى الإعداد & و الإطرونة & الإحماء & & 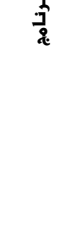 \\
\hline \multirow{3}{*}{5 ق } & \multicolumn{3}{|c|}{65 ق } & \multicolumn{2}{|c|}{20 ق } & \multirow{3}{*}{ 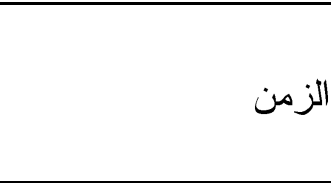 } & \\
\hline & \multicolumn{2}{|c|}{ } & \multirow{2}{*}{ 20 ق } & \multirow{2}{*}{10 ق } & \multirow{2}{*}{10 ق } & & \\
\hline & 10 ق & ت & & & & & \\
\hline تمرينات5 & $1 \cdots-0$ & تمرينات6 & تمرينات5 & تمرينات10 & تمرينات5 & عدد التمرينات & \\
\hline \multicolumn{2}{|c|}{ التذريب الفترى } & الفتريب & \multicolumn{3}{|c|}{ التدريب الفترى منخفض الثدة } & 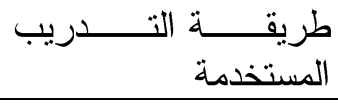 & \\
\hline $\begin{array}{l}-30 \\
\% 40\end{array}$ & $\begin{array}{l}-65 \\
\% 75\end{array}$ & $\begin{array}{l}-75 \\
\% 90\end{array}$ & $\begin{array}{l}-65 \\
\% 75\end{array}$ & \multicolumn{2}{|c|}{$\% 60-50$} & شدة الحمل & \\
\hline & $\begin{array}{c}60-\mu . \\
\\
\end{array}$ & $\begin{array}{c}60-r . \\
ث \\
\end{array}$ & $\begin{array}{c}60-40 \\
ث\end{array}$ & & & 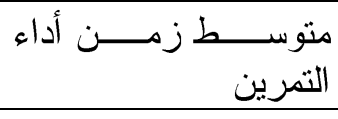 & \\
\hline - & $1: 1$ & $1: 1$ & $1: 1$ & - & - & نسبة الأداء للر احة & \\
\hline & $\begin{array}{c}7 \cdot-30 \\
+\end{array}$ & $\begin{array}{c}60-r . \\
ث\end{array}$ & $\begin{array}{c}60-30 \\
ث \\
\end{array}$ & & & 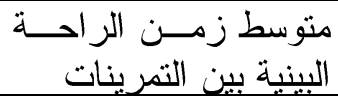 & \\
\hline - & 2 & r & 2 & - & $\longrightarrow$ & عدد مجمو عات الوحدة & \\
\hline & ث & ت & 吾 180 & & & زالمجمو الراحة البينية بين & \\
\hline \multicolumn{6}{|c|}{90 ق } & فيى البرنامج الوحدة التدريبيـــة & \\
\hline \multicolumn{6}{|c|}{ وحدات أسبو عيا ه } & الوحدات فـــــــــــــــات ألأسبو ع ع & \\
\hline \multicolumn{6}{|c|}{ ق ق } & فى الأسبوع وحدات البرنـــامج & \\
\hline \multicolumn{6}{|c|}{ 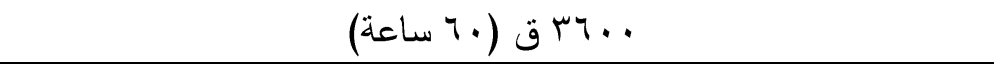 } & زمن وحدات البرنامج & \\
\hline \multicolumn{6}{|c|}{40 وحدة تدرييية } & لمجدم وحة البحث البرنــامج & \\
\hline
\end{tabular}

قام الباحثنان بإستخدام البرنامج الإحصائى SPSS فى إجر اء المعاملات الإحصـائية 


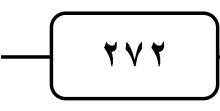

- نسبة التحسن

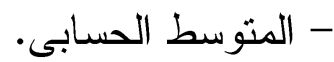
- معامل إيتا 2 - الإنحر اف المعيارى. - معامل التأثير لكوهن.

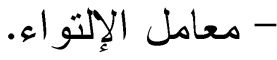
- مستوى الدلالة. - معامل التفلطح. - إختبار (ت) للفروق بين القياسين لمجموعة و احدة.

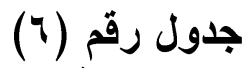

عرض ومناقشة النتائج : الالالات الإحصائية الخاصة بالمتغيرات البدنية لاى عينة الار اسة الأساسية قبل وبعد

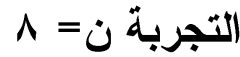

\begin{tabular}{|c|c|c|c|c|c|c|c|c|c|c|c|c|c|}
\hline \multirow{2}{*}{ التحسن: نسبة } & \multirow{2}{*}{ الدالة } & \multirow{2}{*}{ "تيمة } & \multicolumn{2}{|c|}{ الفتوسطين } & \multicolumn{2}{|c|}{ القياسر البعدي } & \multicolumn{2}{|c|}{ القياسر القبلي } & \multirow{2}{*}{ القياس } & \multirow{2}{*}{\multicolumn{3}{|c|}{ اللالاتن الإصطائية }} & \\
\hline & & & $\varepsilon^{ \pm}$ & س & $\varepsilon^{ \pm}$ & 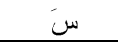 & $\varepsilon^{ \pm}$ & 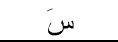 & & & & & \\
\hline \%10.92 & 0.00 & *4.46 & 7.53 & 11.88 & 20.08 & 120.63 & 17.06 & 108.75 & (كجم) & \multicolumn{3}{|c|}{ قوة عضلات الظهربإِستخدام } & \multirow{6}{*}{ 高 } \\
\hline$\% 5.56$ & 0.00 & *13.23 & 2.67 & 12.50 & 10.35 & 237.50 & 11.65 & 225.00 & (سم) & \multicolumn{3}{|c|}{ الوثب العريض من الثبات } & \\
\hline$\% 5.89$ & 0.00 & *4.74 & 0.49 & 0.81 & 0.69 & 14.61 & 0.39 & 13.80 & (متر) & فسة & \multirow{2}{*}{ 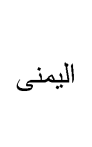 } & 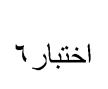 & \\
\hline$\% 3.94$ & 0.03 & *2.81 & 0.12 & 0.12 & 0.08 & 2.89 & 0.06 & 3.01 & (ث) & زمن & & & \\
\hline$\% 5.96$ & 0.00 & *4.53 & 0.51 & 0.83 & 0.80 & 14.68 & 0.40 & 13.85 & (متز) & فمسا & \multirow{2}{*}{ 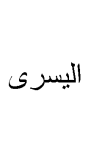 } & الدسافة & \\
\hline$\% 4.55$ & 0.11 & 1.84 & 0.21 & 0.14 & 0.10 & 2.89 & 0.14 & 3.03 & (ث) & زمن & & קرw & \\
\hline$\% 5.56$ & 0.00 & *6.10 & 0.11 & 0.24 & 0.23 & 4.12 & 0.24 & 4.36 & (ث) & \multicolumn{3}{|c|}{ عدو 30 متر من البدء } & \multirow{2}{*}{ السر عة } \\
\hline$\% 4.86$ & 0.01 & *3.97 & 0.12 & 0.17 & 0.25 & 3.36 & 0.27 & 3.53 & (ث) & \multicolumn{3}{|c|}{ عدو 30 متر من البدء } & \\
\hline$\% 29.41$ & 0.01 & *3.91 & 1.36 & 1.88 & 2.25 & 8.25 & 1.60 & 6.38 & (سم) & \multicolumn{3}{|c|}{ ثنى الجذع من الوقوف } & 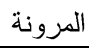 \\
\hline$\% 24.26$ & 0.00 & ${ }^{\star} 5.87$ & 2.95 & 6.13 & 3.34 & 31.38 & 1.28 & 25.25 & (درجة) & \multicolumn{3}{|c|}{ الإنبطاح المائل من الوقوف } & الرشاقة \\
\hline
\end{tabular}

يتضح من الجدول رقم (T) و الشكل البيانى رقم (Y) الخاص بالـــلالات الإحصـــائية الخاصة بالمتغير ات البدنية لدى عينة الدر اسة الأساسية قبل وبعد التجربة وجود فروق دالــة إحصائيا عند مستوي (0. . •) بين القياسين القبلي و البعدي لصالح القياس البعدي في معظـــ

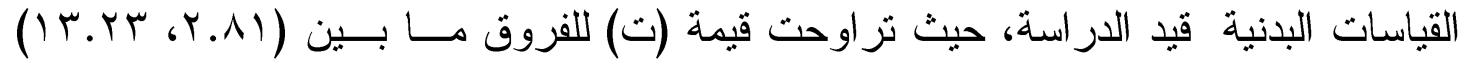
و هى أكبر من قيمة (ت) الجدولية عند مستوى (0. . •) (Y.MV)، كما تراوحت نسب التحسن

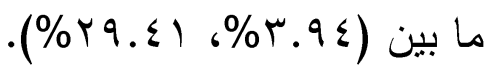
مجلة أسيوط لعلوم وفنوز التربية الرياضية 
rvr

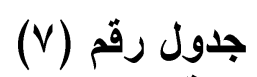

معامل أيتا2 وحجم التأثير لكوهن الخاصة بالمتغيرات البدنية لدى عينة الار اسة الأساسية

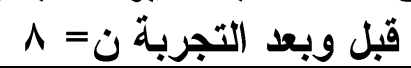

\begin{tabular}{|c|c|c|c|c|c|c|c|c|c|}
\hline مقندار & الكونأثهيم & $\begin{array}{l}\text { ايتنا2 } \\
\text { ايتامل }\end{array}$ & الدلالةت & "تيمة & والقياسة & & \multicolumn{3}{|c|}{ الدهلالهن:لالإيائية } \\
\hline متوسط & 0.59 & 0.74 & 0.00 & 4.46 & (كجم) (كم) & \multicolumn{3}{|c|}{ 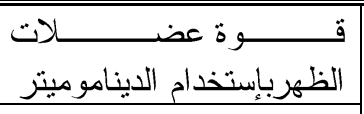 } & \multirow{6}{*}{ 可 } \\
\hline كبير & 0.99 & 0.96 & 0.00 & 13.23 & (سم) & \multicolumn{3}{|c|}{ الوثب العريض من الثبات } & \\
\hline كبير & 1.23 & 0.76 & 0.00 & 4.74 & (متر) & | مسافة & \multirow{2}{*}{ اليمنى } & اختبار 7 & \\
\hline كبير & 1.74 & 0.53 & 0.03 & 2.81 & (ث) & زمن & & 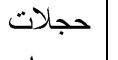 & \\
\hline كبير & 0.91 & 0.75 & 0.00 & 4.53 & (متر) & مسافة & \multirow{2}{*}{\multicolumn{2}{|c|}{\begin{tabular}{r|r|} 
و المسافة & و اليسر \\
\end{tabular}}} & \\
\hline 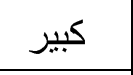 & 1.15 & 0.33 & 0.11 & 1.84 & (ث) & زمن & & & \\
\hline 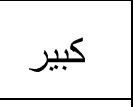 & 1.04 & 0.84 & 0.00 & 6.10 & (ث) & \multicolumn{3}{|c|}{ المنخفض 30 متر من البــدء } & \multirow{2}{*}{ 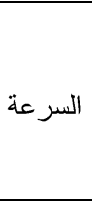 } \\
\hline منوسط & 0.65 & 0.69 & 0.01 & 3.97 & (ث) & \multicolumn{3}{|c|}{ الطائر 30 متر من البــــ } & \\
\hline كبير & 0.87 & 0.69 & 0.01 & 3.91 & (سم) & \multicolumn{3}{|c|}{ ثنى الجذع من الوقوف } & 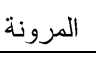 \\
\hline 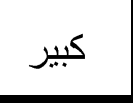 & 2.13 & 0.83 & 0.00 & 5.87 & (درجة) & \multicolumn{3}{|c|}{ 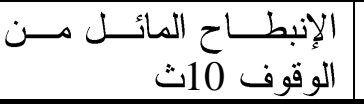 } & الرشاقة \\
\hline
\end{tabular}

*التأثبر (ضعيف) أقل من ه. • *التأثير (متوسط) من 0. • حتى أقل من ^. . *التنأثير (كبير) ^. ، فأكثر

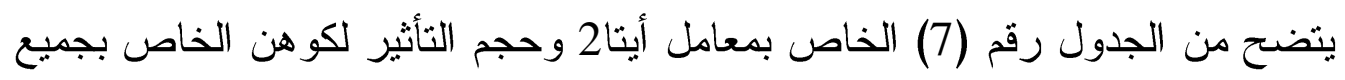

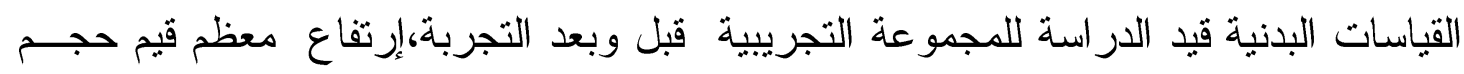

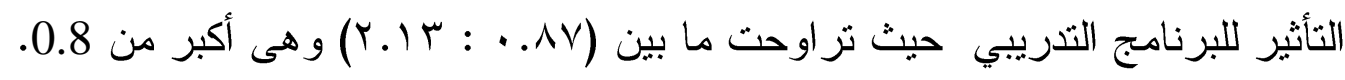

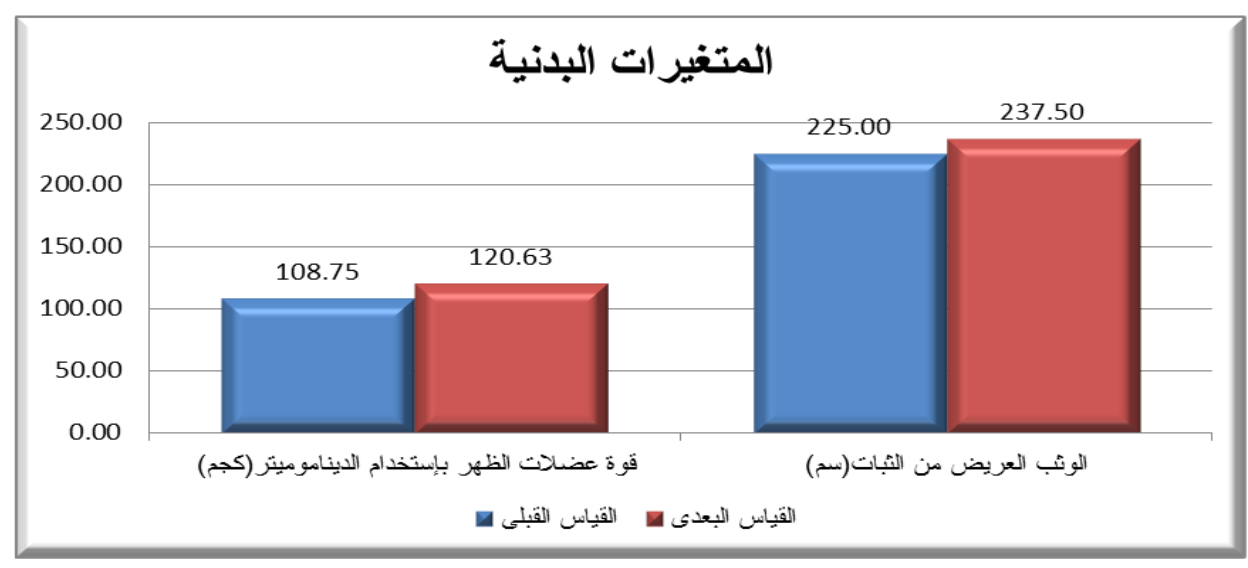




\section{YV}
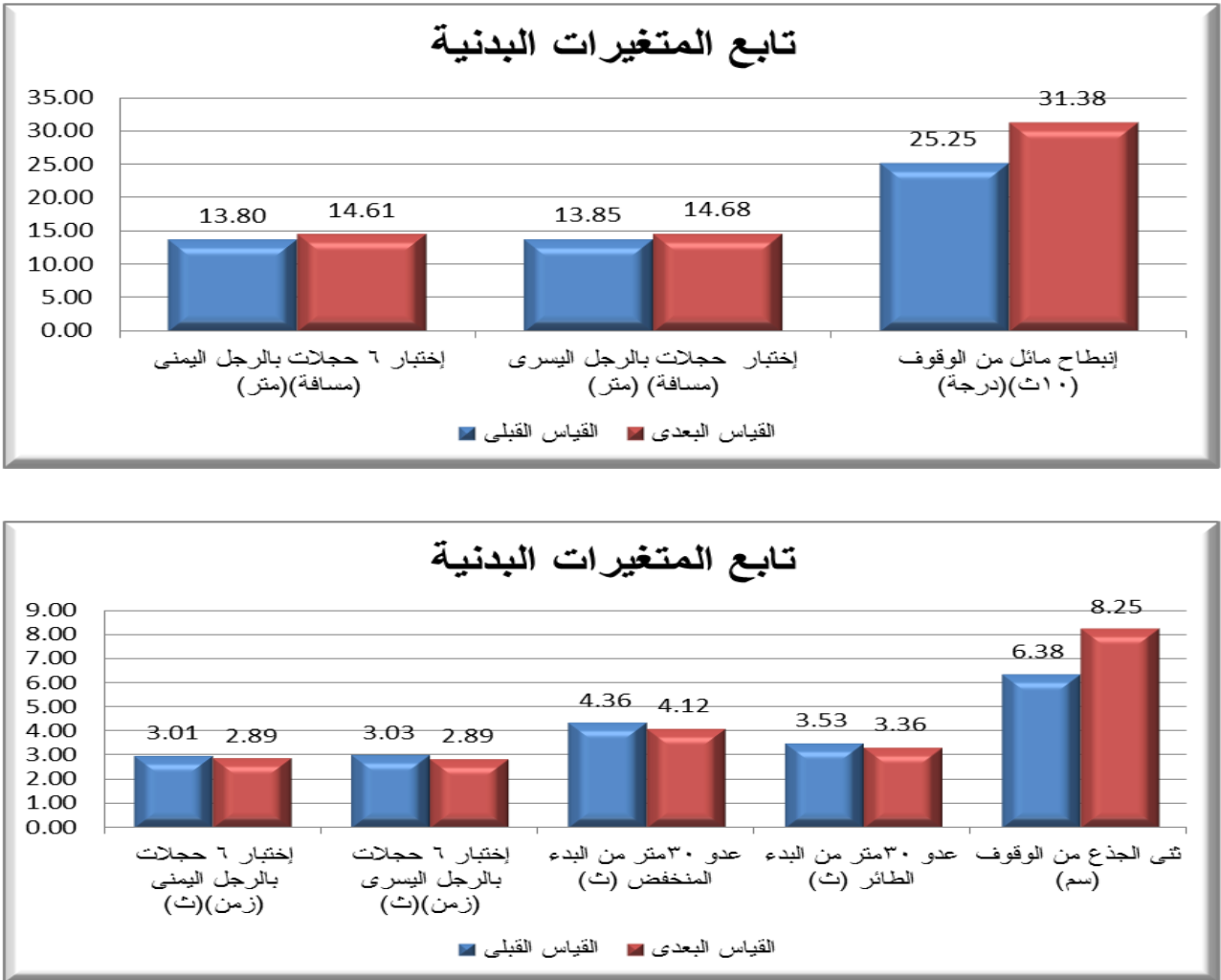

الثكل البيانى رقم (Y) الخاص بالمتوسطات الحسابية للمجموعة التجريبية للقياسات البدنية

\section{قبل وبعد التجربة}

يتضح من عرض النتائج السابقة التي تظهر حجم التأثير المرتفع الي فاعلية البرنامج التدريبى بإستخدام تمرينات S.A.Q فى تحسن القياسات البدنية قيد البحث، حيث تـم وضــع

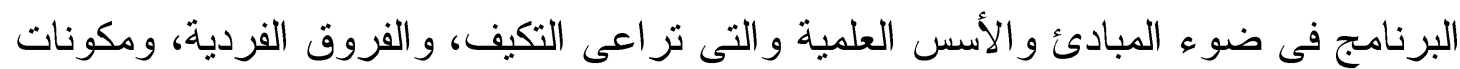
حمل التدريب، حيث يتضح من الجدول رقم (T) والثكل البيانى رقم (Y) الخاص بالـــلالات الإحصائية الخاصة بالمتغير ات البدنية و الجدول رقم (7) الخاص بمعامل أيتا2 وحجم التـأثثر لكوهن الخاصة بالمتغير ات البدنية لدى عينة الدراسة الأساسية قبل وبعد التجربة وجود فروق دالة إحصائياً عند مستوي (0. . .) بين القياسين القبلي والبعدي لصالح القياس البعـدي فــي

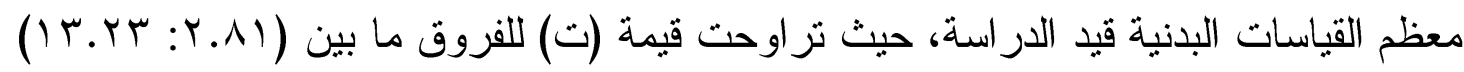
و هى أكبر من قيمة (ت) الجدولية عند مستوى (0. . •) (Y.MV)، كما تراوحت نسب التحسن

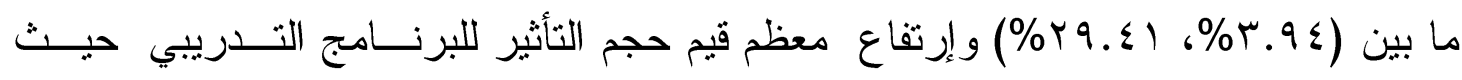

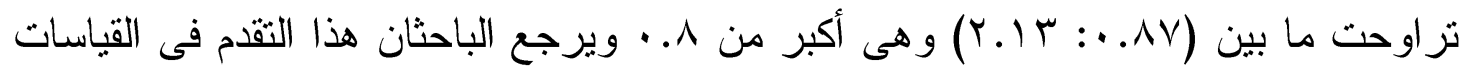

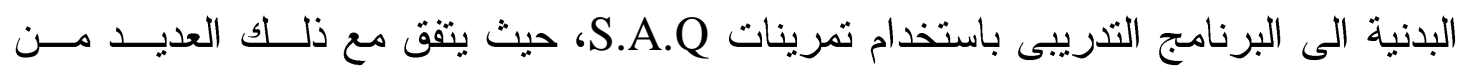




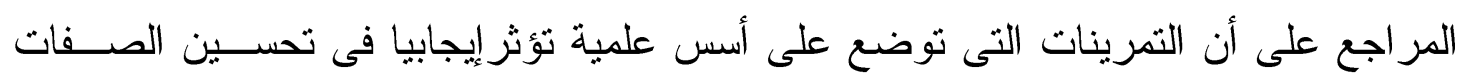

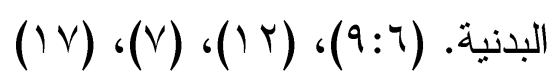

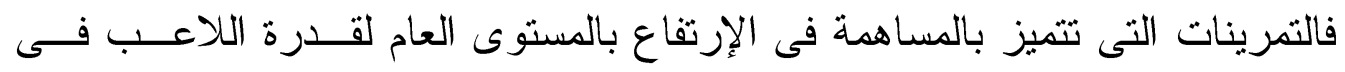

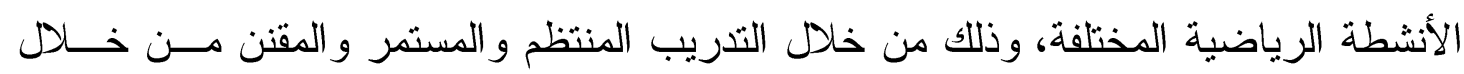

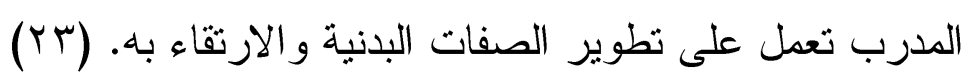

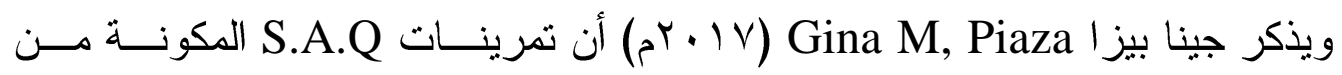

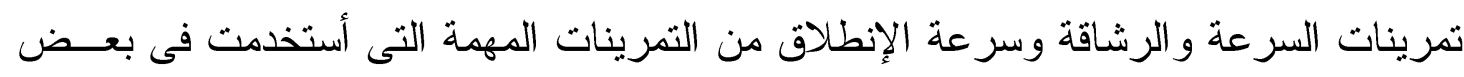

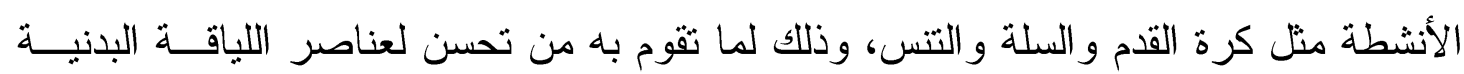

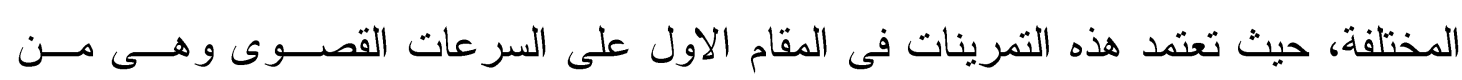

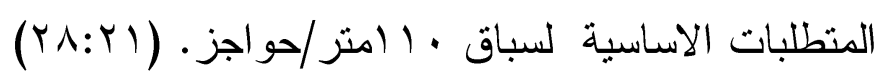

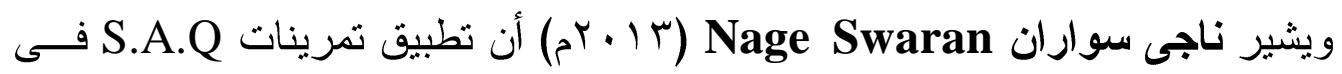

البرامج التدريبية والتى توضع على أسس علمية من الطرق الفعالة فى تحسين القدرات البدنية و التى لها اثر ايجابى كبير فى نجاح عملية تخطيط برامج التدريب وتحقيق الأهداف المطلوبة.

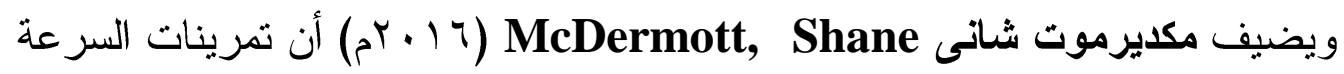

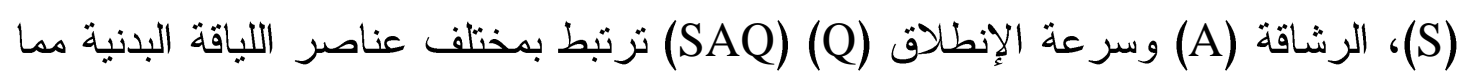

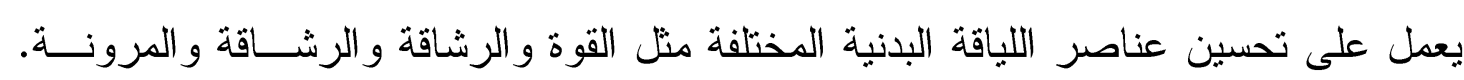

ويؤكد كل من زوران ميلاســوفيش A. C. Zoran Milanović

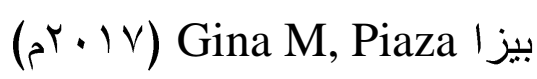
أن تمرينات (SAQ) تعمل على تحسين اللياقة البدنية لاى اللاعبين التـى تــؤهلهم

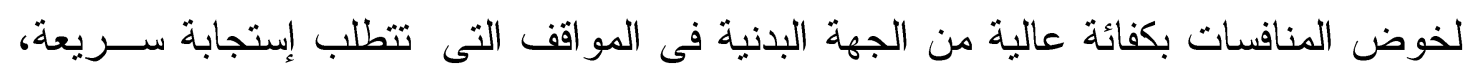

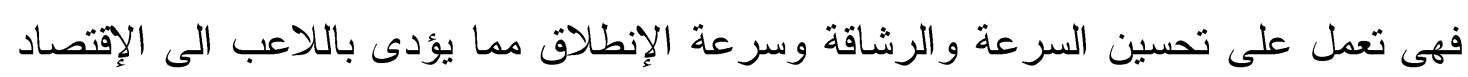

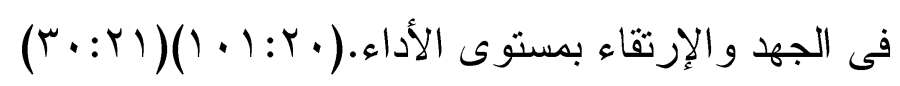

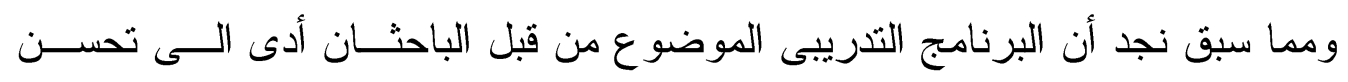

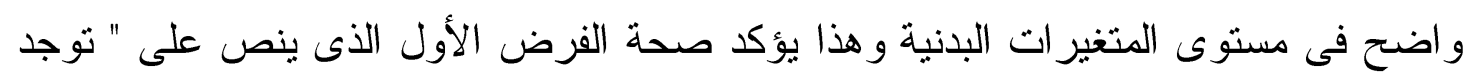

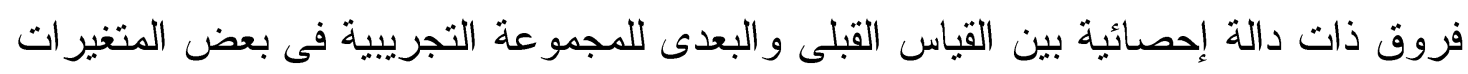

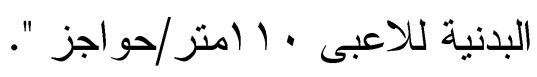




\section{rVY}

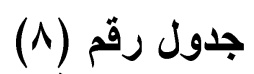

الالالات الإحصائية الخاصة بالمتغيرات الكينماتيكية لخطوة الحاجز الأول الحئ لاى عينة الدراسة

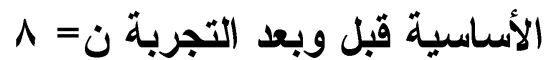

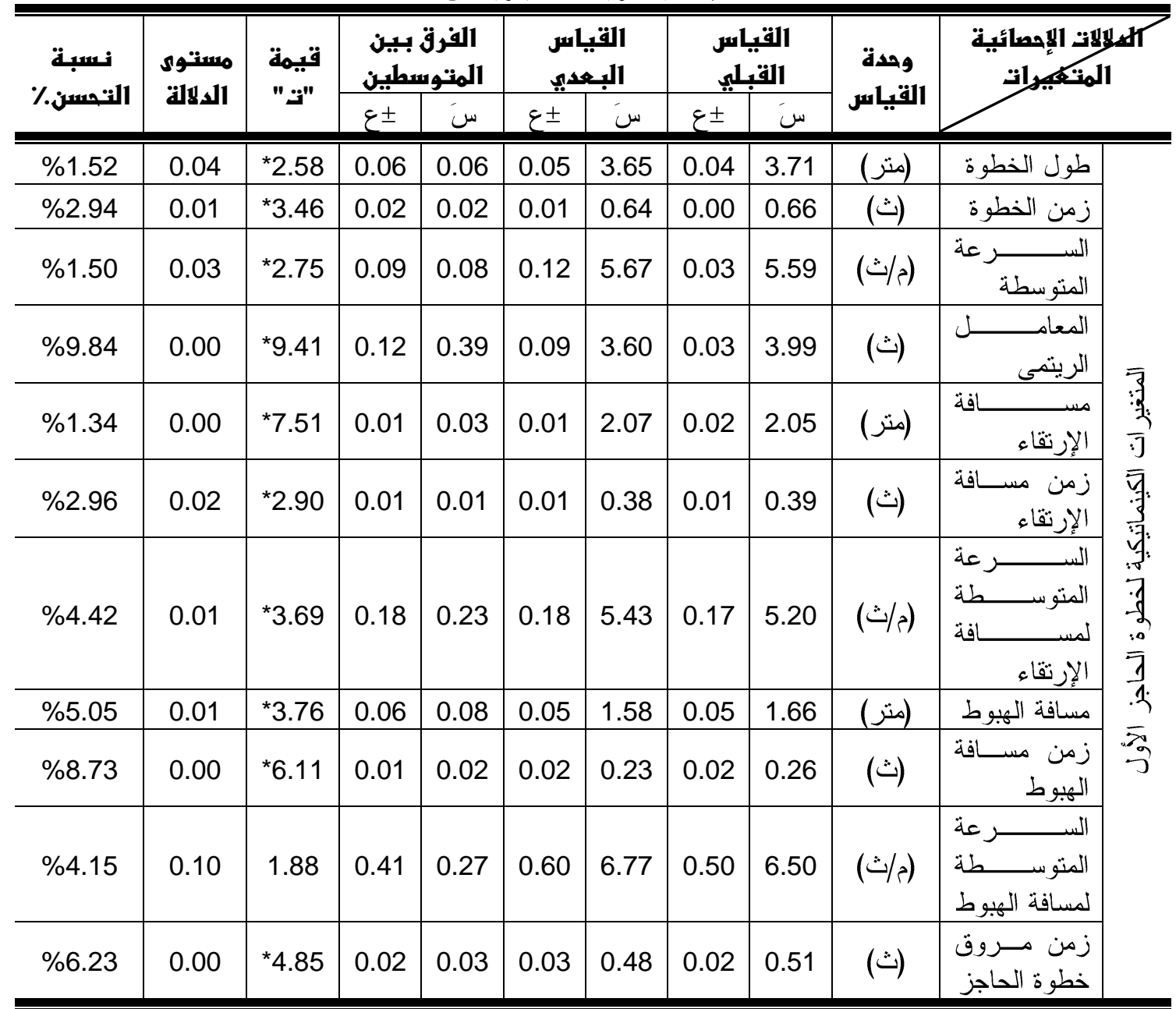

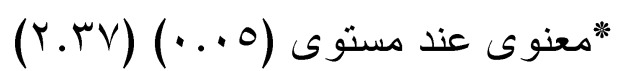

يتضح من الجدول رقم (^) و الثُكل البيانى رقم (ץ) الخاص بالـــلالات الإحصــائية

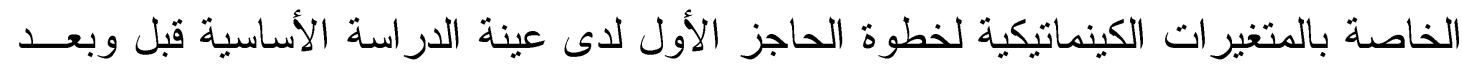

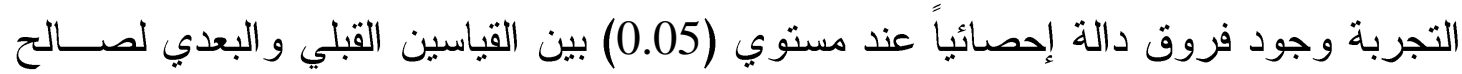
القياس البعدي في معظم المتغير ات الكينماتيكية قيد الدر اسة، حيث تر اوحت قيمة (ت) للفروق

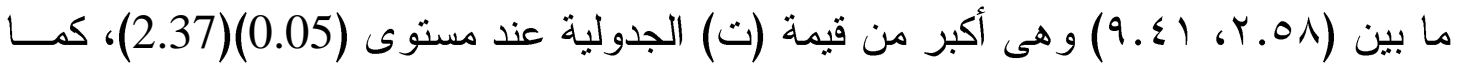

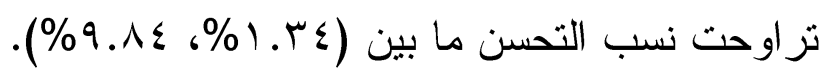




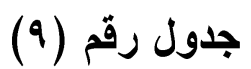

معامل أيتا2 وحجم التأثير لكوهن الخاصة بالمتغيرات الكينماتيكية لخطوة الحئة الحاجز الأول لاى

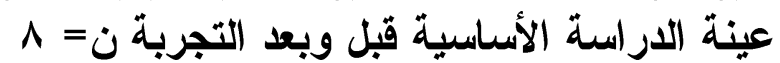

\begin{tabular}{|c|c|c|c|c|c|c|c|}
\hline التأثيرار & للكوهن & 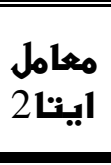 & الدستولة & "تيمة & والقياس & لالات الإصصائية & \\
\hline كبير & 1.23 & 0.49 & 0.04 & 2.58 & (متر) & طول الخطوة & \\
\hline كبير & 2.41 & 0.63 & 0.01 & 46 & (ث) & زمن الخطوة & \\
\hline ضعيف & 0.11 & 0.52 & 0.03 & 2.75 & 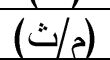 & السر عة المتوسطة & \\
\hline كبيز & 6.58 & 0.93 & 0.00 & 9.41 & (ث) & المعامل الريتمى & : \\
\hline كبير & 1.24 & 0.89 & 0.00 & 7.51 & (متر) & مسافة الإرنقاء & . \\
\hline كبير & 0.92 & 0.55 & 0.02 & 2.90 & (ث) & زمن مسافة الإرتقاء & $z^{3}$ \\
\hline كبيز & 1.33 & 0.66 & 0.01 & 3.69 & (ה/ث) & 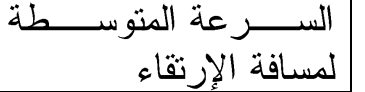 & 7 \\
\hline كبير & 1.76 & 0.67 & 0.01 & 3.76 & (متز) & مسافة الهبوط & \\
\hline كبير & 1.34 & 0.84 & 0.00 & 6.11 & (ث) & زمن مسافة الهيوط & $\overline{3}$ \\
\hline ضعيف | | | ل & 0.48 & 0.34 & 0.10 & 1.88 & (ה/ث) & 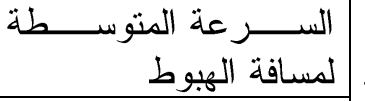 & \\
\hline كبير & 1.22 & 0.77 & 0.00 & 4.85 & (ث) & زالحاجزن مــروق خطــــوة & \\
\hline
\end{tabular}

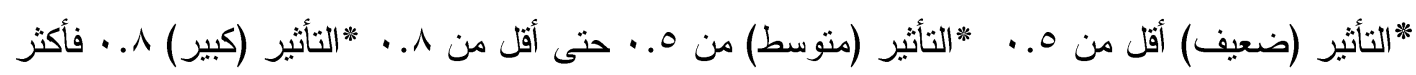

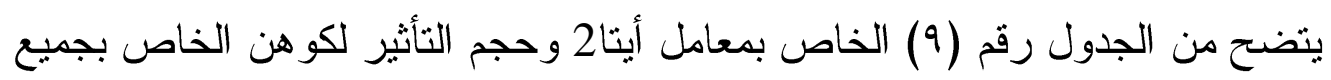

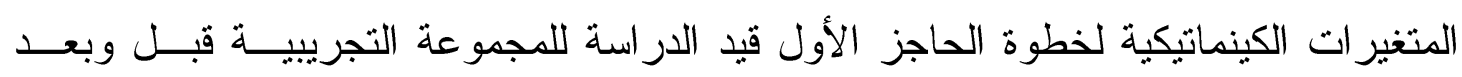

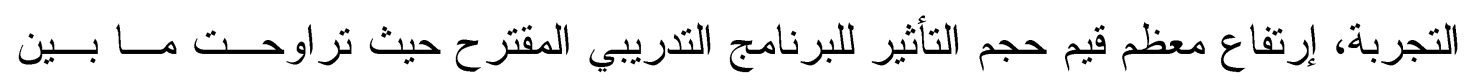

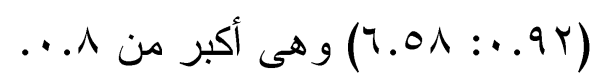

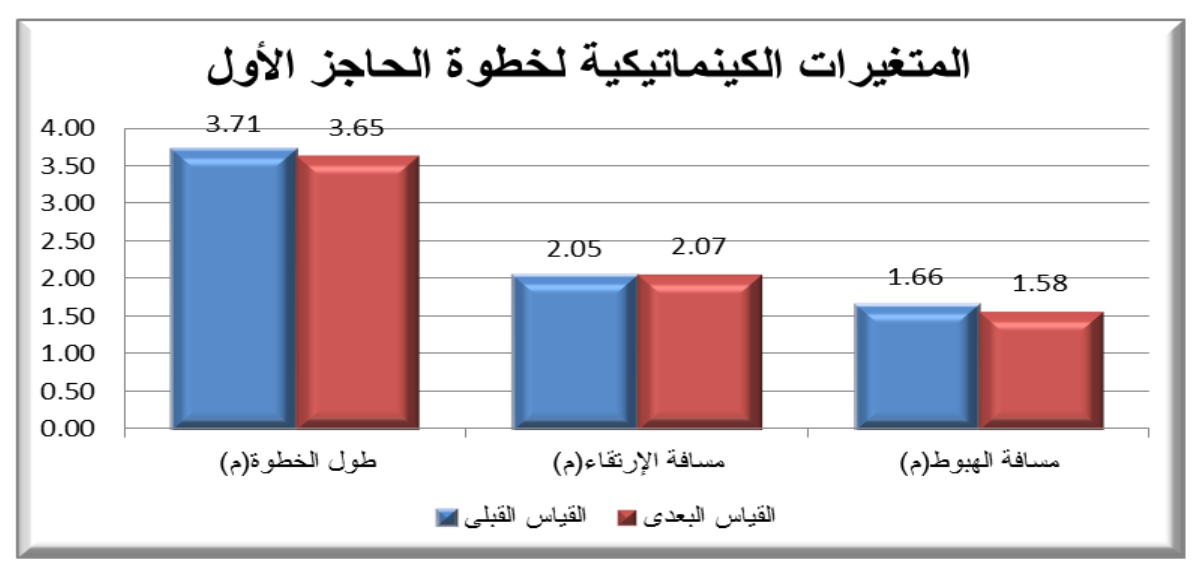



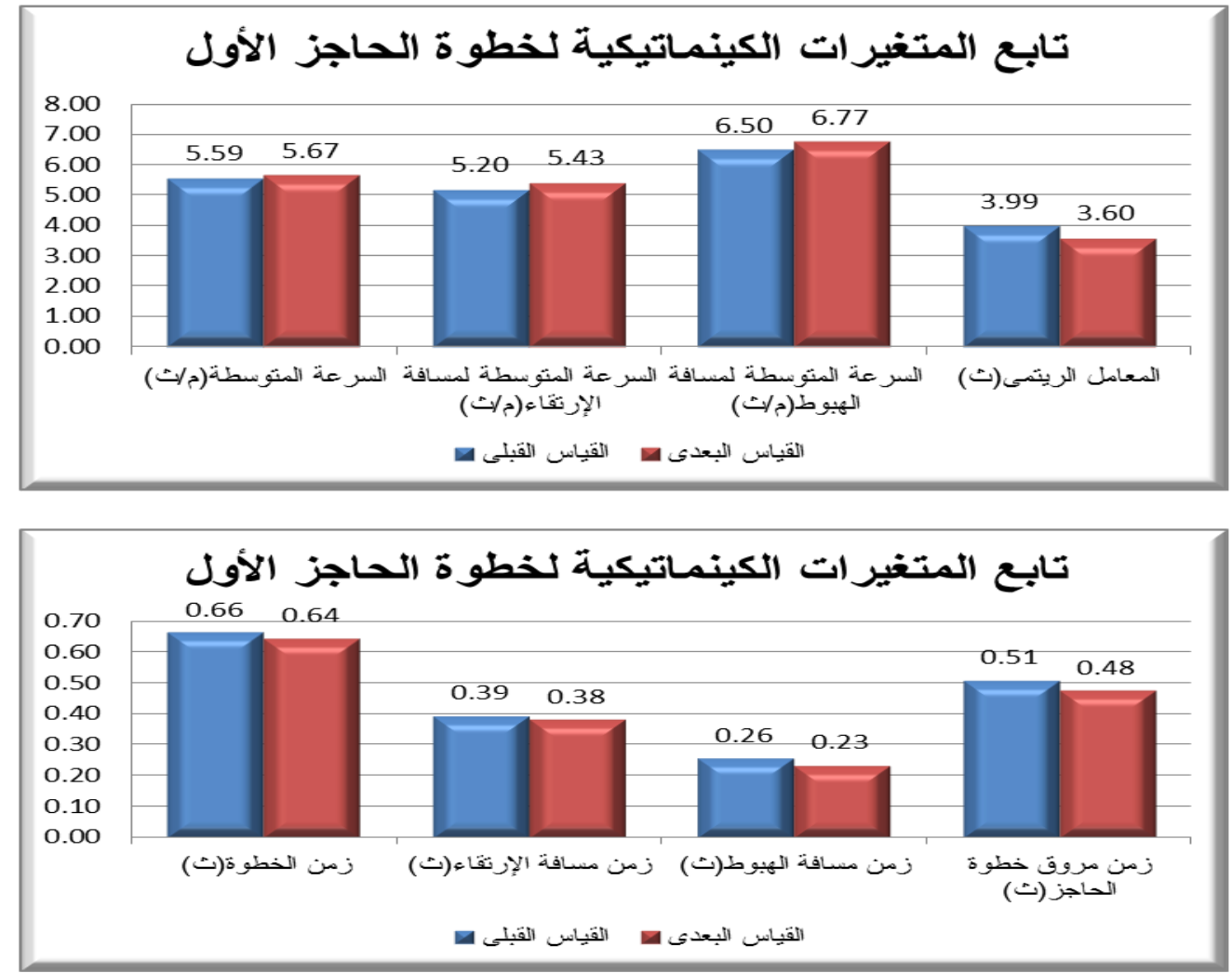

الشكل البيانى رقم (r) الخاص بالمتوسطات الحسابية للمجموعة التجريبية للمتغيرات الكينماتيكية لخطوة الحاجز الأول قبل وبعد التجربة

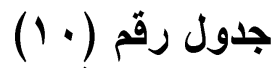

الالالات الإحصائية الخاصة بالمتغيرات الكينماتيكية لخطوة الحاجز الثانى لاى عينة الدراسة الأساسية قبل وبعد التجربة ن

\begin{tabular}{|c|c|c|c|c|c|c|c|c|c|c|c|}
\hline \multirow{2}{*}{ 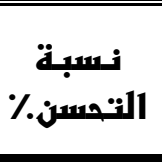 } & \multirow{2}{*}{ الدلاستوك } & \multirow{2}{*}{ "تيمة } & \multicolumn{2}{|c|}{ المتورسطين بين } & \multicolumn{2}{|c|}{ البـعدير القياس } & \multicolumn{2}{|c|}{ القبياسير } & \multirow{2}{*}{ القياسة ودة } & \multirow{2}{*}{\multicolumn{2}{|c|}{ المتنغيراتهائلانة }} \\
\hline & & & $\varepsilon \pm$ & سَ & $\varepsilon \pm$ & سَ & $\varepsilon \pm$ & سَ & & & \\
\hline$\% 0.51$ & 0.56 & 0.61 & 0.09 & 0.02 & 0.03 & 3.68 & 0.07 & 3.66 & (متر) & الخطوة & \\
\hline$\% 2.65$ & & 1.94 & 0.03 & 0.02 & 0.03 & 0.63 & 0.02 & 0.65 & (ث) & الخطوة زمن & \\
\hline$\% 3.10$ & 0.02 & *3.19 & 0.16 & 0.18 & 0.29 & 5.82 & 0.19 & 5.65 & (خ/ث) & المتوسطة السر عة & \\
\hline$\% 2.91$ & & 1.09 & 0.25 & 0.10 & 0.18 & 3.44 & 0.16 & 3.35 & (ث) & الريتمى & $\frac{-10}{17}$ \\
\hline$\% 0.92$ & 0.02 & *2.93 & 0.02 & 0.02 & 0.02 & 2.06 & 0.01 & 2.05 & (متر) & الإرتقاءة & 歌 \\
\hline
\end{tabular}




\section{rva}

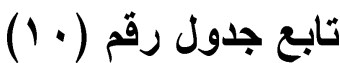

الالالات الإحصائية الخاصة بالمتغيرات الكينماتيكية لخطوة الحئ الحاجز الثانى لاى عينة الاراسة الأساسية قبل وبعد التجربة ن

\begin{tabular}{|c|c|c|c|c|c|c|c|c|c|c|}
\hline \multirow{3}{*}{ 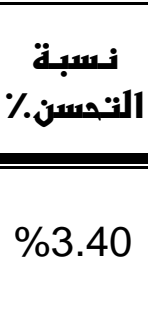 } & \multirow{3}{*}{ 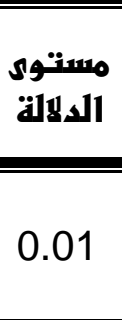 } & \multirow{3}{*}{$\begin{array}{l}\text { "تيهة" } \\
\text { "3.28 }\end{array}$} & \multicolumn{2}{|c|}{ المتوسطين } & \multicolumn{2}{|c|}{ البـعدياس } & \multicolumn{2}{|c|}{ القباسلي } & \multirow{3}{*}{ القياسة وحدة } & \multirow{2}{*}{ 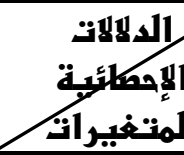 } \\
\hline & & & $\varepsilon^{ \pm}$ & سَ & $\varepsilon \pm$ & سَ & $\varepsilon \pm$ & سَ & & \\
\hline & & & 0.01 & 0.01 & 0.01 & 0.38 & 0.01 & 0.39 & & مسافة \\
\hline$\% 4.40$ & 0.01 & *3.48 & 0.19 & 0.23 & 0.16 & 5.43 & 0.17 & 5.20 & (م/ث) & المتوسطة المسة \\
\hline$\% 0.00$ & 1.00 & 0.00 & 0.10 & 0.00 & 0.03 & 1.61 & 0.08 & 1.61 & (متر) & الهبوطة \\
\hline$\% 5.05$ & 0.02 & ${ }^{\star} 2.87$ & 0.01 & 0.01 & 0.01 & 0.24 & 0.02 & 0.25 & (ث) & زمنافة \\
\hline$\% 5.22$ & 0.12 & 1.77 & 0.53 & 0.33 & 0.37 & 6.68 & 0.49 & 6.35 & (م/ث) & المتوسطة المسة \\
\hline$\% 4.57$ & 0.02 & *2.99 & 0.02 & 0.02 & 0.03 & 0.49 & 0.02 & 0.51 & (ث) & زرون زمن \\
\hline
\end{tabular}

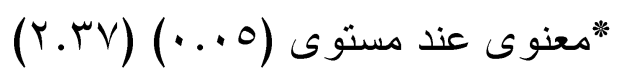

يتضح من الجدول رقم (· () و الثكل البيانى رقم (ع) الخاص بالدلالات الإحصـائية

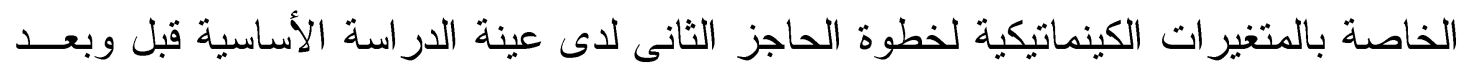

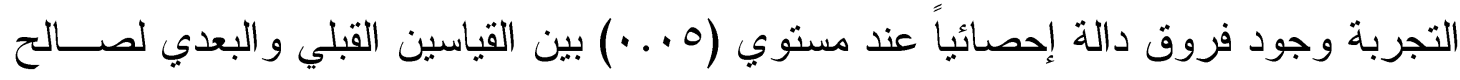
القياس البعدي في بعض المتغير ات الكينماتيكية قيد الدراسة، حيث تر اوحت قيمة (ت) للفروق

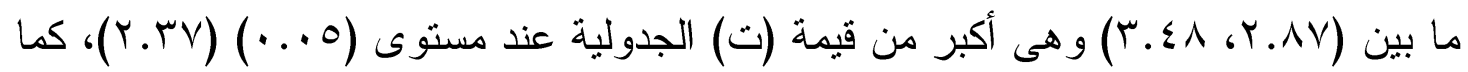

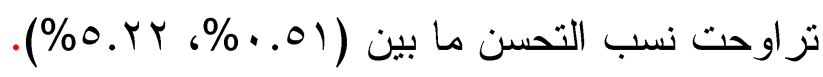


r^.

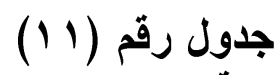

معامل أيتا2 وحجم التأثير لكوهن الخاصة بالمتغيرات الكينماتيكية لخطوة الحاجز الثانى لاى الثي

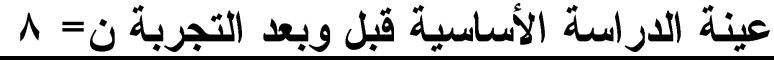

\begin{tabular}{|c|c|c|c|c|c|c|}
\hline النأثيدر & لكوأنأثر & $\begin{array}{l}\text { 1يتاما } \\
\text { 1 معام }\end{array}$ & الدلالة & "تيمة & والقياس & 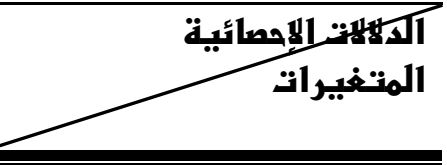 \\
\hline ضعيف & 0.34 & 0.05 & 0.56 & 0.61 & (متر) & طول الخطوة \\
\hline 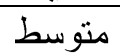 & 0.62 & 0.35 & 0.09 & 1.94 & (ث) & زمن الخطوة \\
\hline متوسط & 0.56 & 0.59 & 0.02 & 3.19 & (ث/د) & الم السر عة المتوسطة \\
\hline متوسط & 0.57 & 0.15 & 0.31 & 1.09 & (ث) & ا \\
\hline كبير & 1.20 & 0.55 & 0.02 & 2.93 & (متر) (متر) & مسافة الإرتقاء \\
\hline كبير & 1.06 & 0.61 & 0.01 & 3.28 & (ث) & 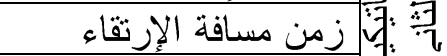 \\
\hline كبير & 1.39 & 0.63 & 0.01 & 3.48 & (ث) & 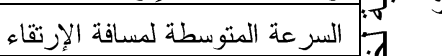 \\
\hline ضعيف & 0.00 & 0.00 & 1.00 & 0.00 & (متر) (متر) & مه -1 مسافة الهبوط \\
\hline كبير & 0.81 & 0.54 & 0.02 & 2.87 & (ث) & زمن مسافة الهبوط \\
\hline متوسط & 0.76 & 0.31 & 0.12 & 1.77 & (ث/A) & |مالسر عة المتوسطة لسسافة الهيوط \\
\hline كبير & 0.81 & 0.56 & 0.02 & 2.99 & (ث) & | زمن مروق خطوة الحاجز \\
\hline
\end{tabular}

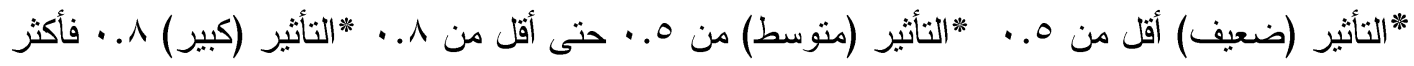

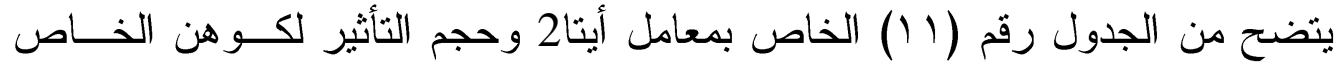

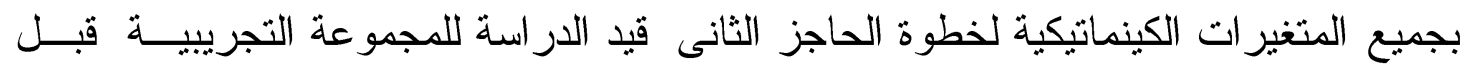

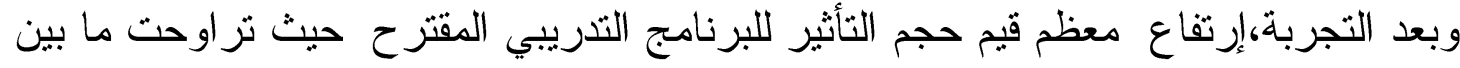
(...
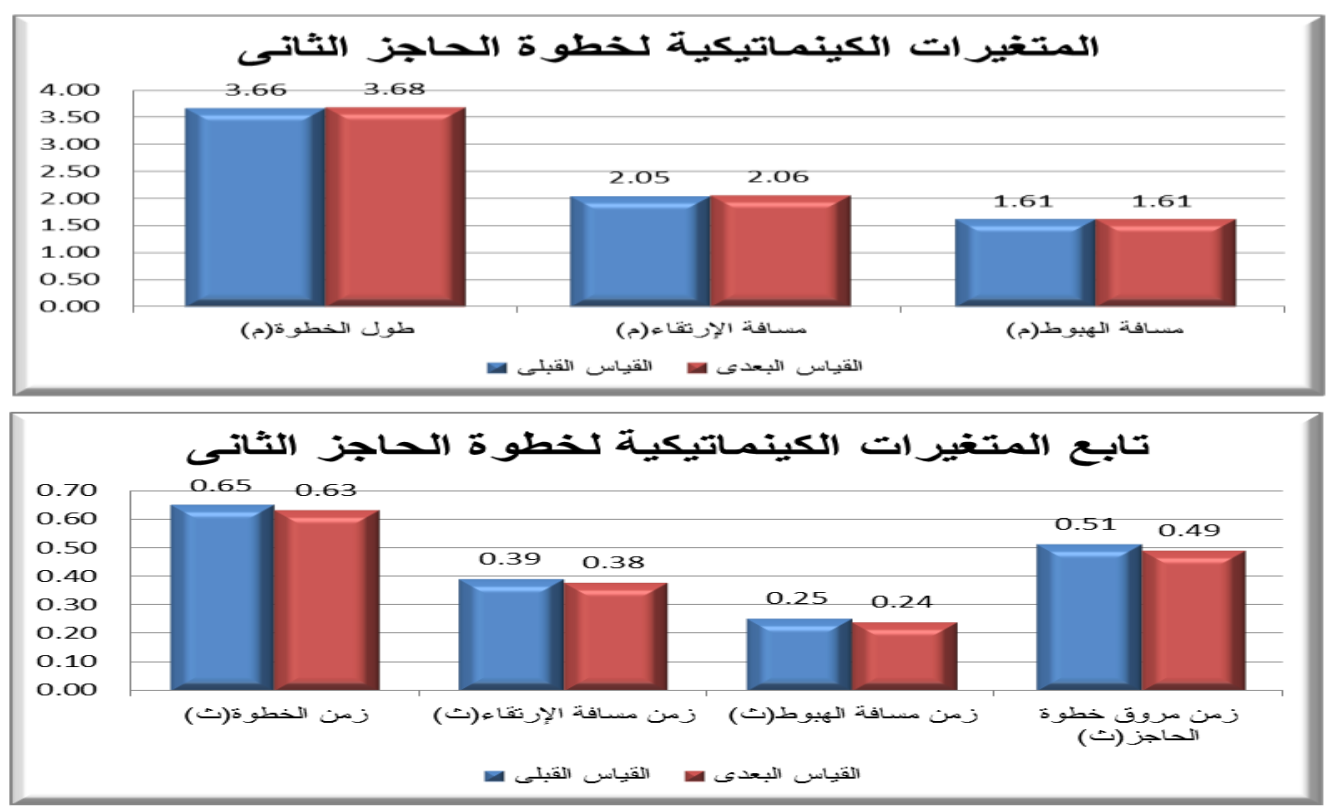

مجلة أسيوط لعلوم وفنـوز التربية الرباضية 


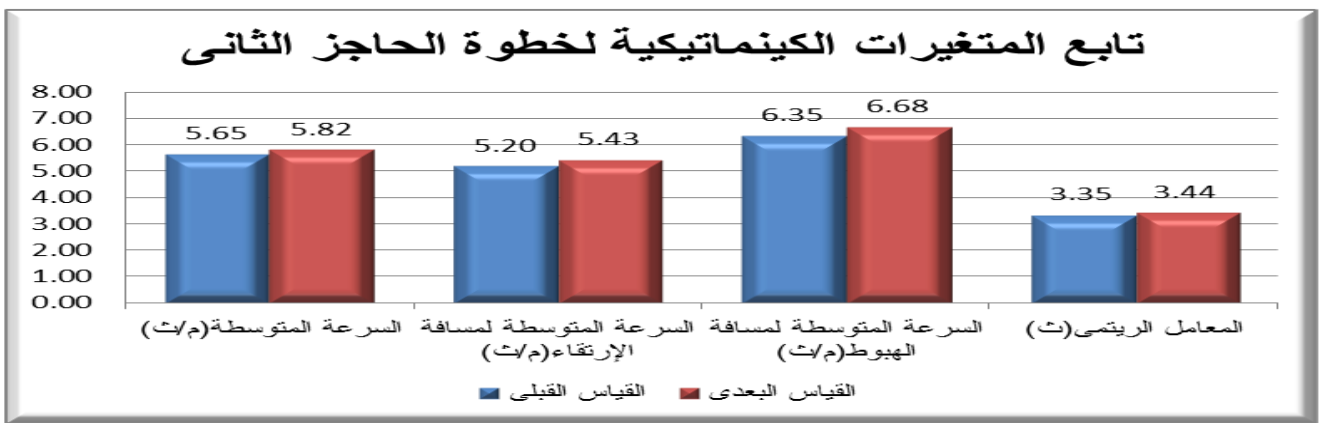

الشكل البيانى رقم (ع) الخاص بالمتوسطات الحسابية للمجموعة التجريبية للمتغيرات الكينماتيكية لخطوة الحاجز الثانى قبل وبعد التجربة

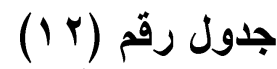

الالالات الإحصائية الخاصة بالمتغيرات الكينماتيكية لخطوة الحاجز الثالث لاى عينة الدراسة الأساسية قبل وبعد التجربة ن

\begin{tabular}{|c|c|c|c|c|c|c|c|c|c|c|c|}
\hline \multirow{2}{*}{ التنسبنة } & \multirow{2}{*}{ مستوك الدالة } & \multirow{2}{*}{ "تيمة } & \multicolumn{2}{|c|}{ الفتوسطين } & \multicolumn{2}{|c|}{ القياسر البعدي } & \multicolumn{2}{|c|}{ القياسر القبلي } & \multirow{2}{*}{ والقياسـة } & \multirow{2}{*}{\multicolumn{2}{|c|}{ آلكلالات الإصصائية }} \\
\hline & & & $\varepsilon^{ \pm}$ & سن & $\varepsilon^{ \pm}$ & سن & $\varepsilon^{ \pm}$ & سن & & & \\
\hline$\% 0.41$ & 0.32 & 1.07 & 0.04 & 0.01 & 0.03 & 3.67 & 0.04 & 3.65 & (متر) & طول الخطوة & \\
\hline$\% 5.70$ & 0.00 & 10.27 & 0.01 & 0.04 & 0.03 & 0.61 & 0.02 & 0.64 & (ث) & زمن الخطوة & \\
\hline$\% 6.58$ & 0.00 & *7.39 & 0.14 & 0.37 & 0.28 & 6.04 & 0.18 & 5.67 & (م/ث) & 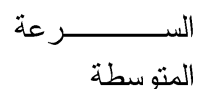 & \\
\hline$\% 11.17$ & 0.26 & 1.22 & 0.94 & 0.41 & 0.09 & 3.23 & 0.92 & 3.64 & (ث) & المعامل الريتمى & $: 9$ \\
\hline$\% 0.85$ & 0.02 & *2.97 & 0.02 & 0.02 & 0.02 & 2.07 & 0.01 & 2.05 & (منر) & مسافة الإرتثاء & $\overline{3}$ \\
\hline$\% 1.86$ & 0.10 & 1.89 & 0.01 & 0.01 & 0.02 & 0.40 & 0.03 & 0.40 & (ث) & 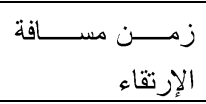 & 隅 \\
\hline$\% 2.65$ & 0.04 & *2.45 & 0.16 & 0.14 & 0.30 & 5.24 & 0.36 & 5.10 & (م/ث) & لسافة الإرتقاء الستوة & , \\
\hline$\% 0.00$ & 1.00 & 0.00 & 0.06 & 0.00 & 0.04 & 1.60 & 0.04 & 1.60 & (متر) & مسافة الهبوط & 1 \\
\hline$\% 8.06$ & 0.01 & *3.64 & 0.02 & 0.02 & 0.01 & 0.23 & 0.01 & 0.25 & (ث) & زلهيـــن مســـــافة & . \\
\hline$\% 9.11$ & 0.01 & *3.96 & 0.42 & 0.58 & 0.50 & 6.96 & 0.18 & 6.38 & (م/ث) & لمسافة الهبوط المتوسطة & \\
\hline$\% 3.60$ & 0.00 & ${ }^{*} 4.72$ & 0.01 & 0.02 & 0.02 & 0.49 & 0.02 & 0.51 & (ث) & زمـــن مـــروق & \\
\hline
\end{tabular}

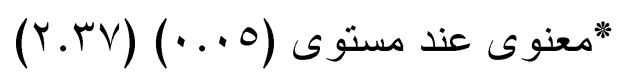

يتضح من الجدول رقم (Y I) و الشكل البيانى رقم (0) الخاص بالدلالات الإحصــائية

الخاصة بالمتغير ات الكينماتيكية لخطوة الحاجز الثالث لدى عينة الدر اسة الأساسية قبل وبعـد التجربة وجود فروق دالة إحصائياً عند مستوي (0 . . ) بين القياسين القبلي و البعدي لصــالح 
القياس البعدي في معظم المتغير ات الكينماتيكية قيد الدراسة، حيث تراوحت قيمة (ت) للفروق

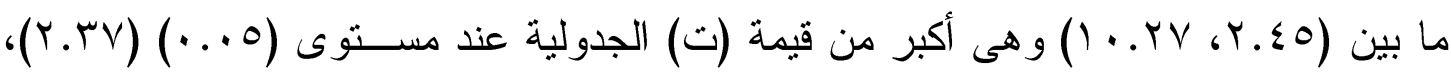

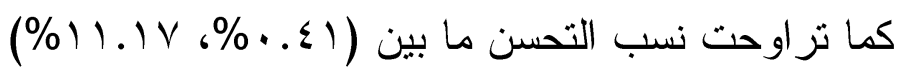
جدول رقم (IT)

معامل أيتا2 وحجم التأثير لكوهن الخاصة بالمتغيرات الكينماتيكية لخطوة الحاجز الثالث لاى

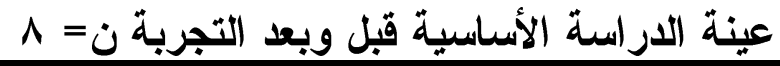

\begin{tabular}{|c|c|c|c|c|c|c|c|}
\hline التأثئرار & الكتأثني & 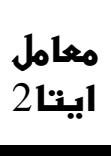 & الدسلالة & "تيمة & والقياس & لالانت الإصصائية & \\
\hline ضعيف & 0.39 & 0.14 & 0.32 & 1.07 & (متر) & طول الخطوة & \\
\hline كبير & 1.22 & 0.94 & 0.00 & 10.27 & (ث) & زمن الخطوة & \\
\hline كبير & 1.14 & 0.89 & 0.00 & 7.39 & (ث) & السر عة المتوسطة & \\
\hline متوسط & 0.65 & 0.18 & 0.26 & 1.22 & (ث) & المعامل الريتمى & . \\
\hline كبير & 1.03 & 0.56 & 0.02 & 2.97 & (متر) & مسافة الإرتقاء & 呵 \\
\hline ضعيف & 0.25 & 0.34 & 0.10 & 1.89 & (ث) & زمن مسافة الإرتقاء & \\
\hline ضعيف & 0.38 & 0.46 & 0.04 & 2.45 & (م/ث) & 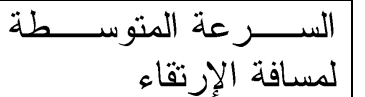 & -1 \\
\hline ضعيف & 0.00 & 0.00 & 1.00 & 0.00 & (متز) & مسافة الهيوط & 7 \\
\hline كبير & 1.80 & 0.65 & 0.01 & 3.64 & (ث) & زمن مسافة الهيوط & \\
\hline كبيز & 1.25 & 0.69 & 0.01 & 3.96 & (a/ث) & 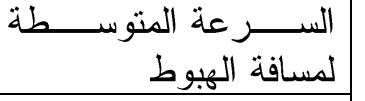 & 弱 \\
\hline كبير & 0.82 & 0.76 & 0.00 & 4.72 & (ث) & لزمـــن مـروق خطــوة & \\
\hline
\end{tabular}

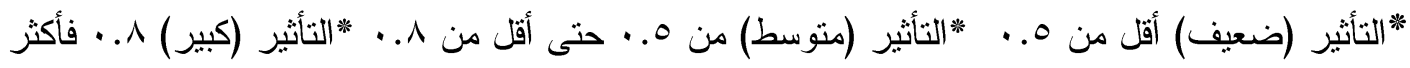

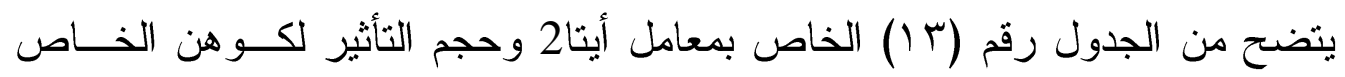

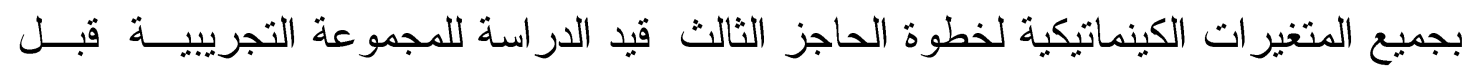

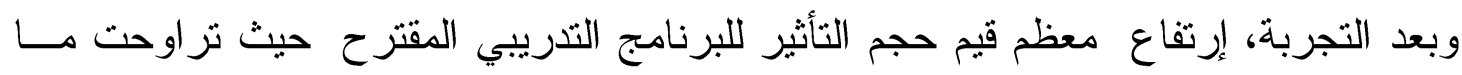

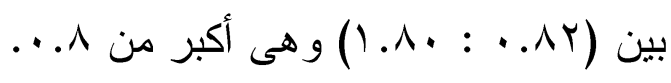

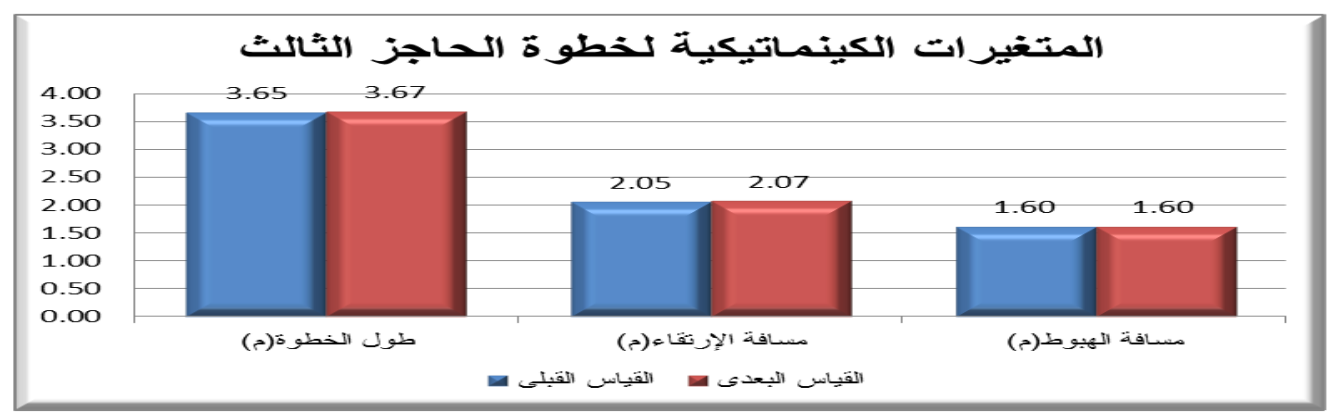




\section{rAT}

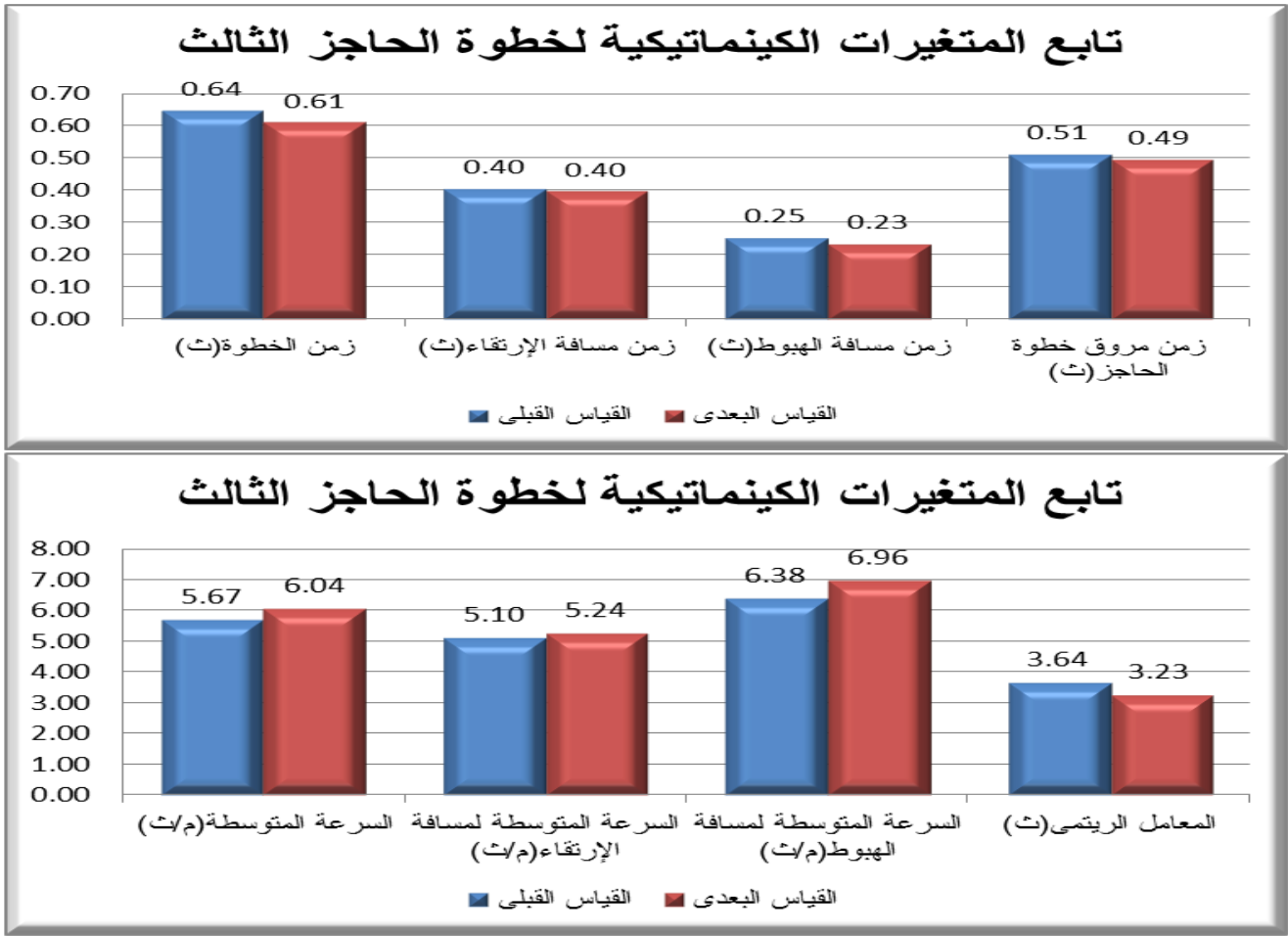

الشكل البيانى رقم (0) الخاص بالمتوسطات الحسابية للمجموعة التجريبية للمتغيرات

\section{الكينماتيكية لخطوة الحاجز الثالث قبل وبعد التجربة}

يتضح من الجداول الخاصة بمرحلة بناء السرعة والمتمثلة فى جدول رقم (8) و الشكل البيانى رقم (r) الخاص بالدلالات الإحصائية الخاصة بالمتغيرات الكينماتيكية لخطوة الحاجز

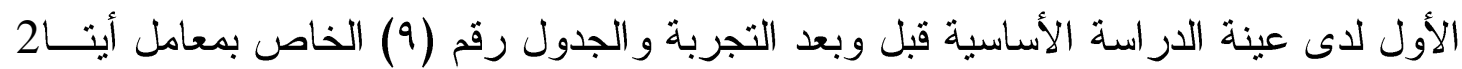
وحجم التأثير لكوهن الخاص بجميع المتغير ات الكينماتيكية لخطوة الحاجز الأول قبد الدراســة للمجموعة التجريبية قبل وبعد التجربة وجود فروق دالة إحصائياً عند مستوي (0. . .) بـين القياسين القبلي و البعدي لصالح القياس البعدي في معظم المتغيرات الكينماتيكية قبد الدراســة،

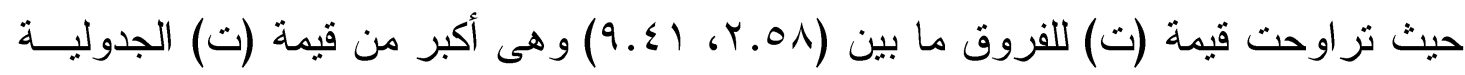

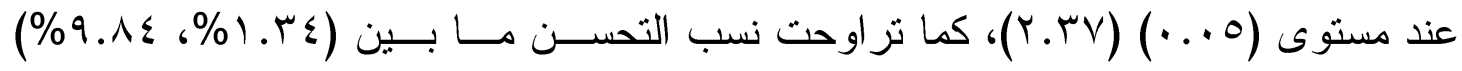

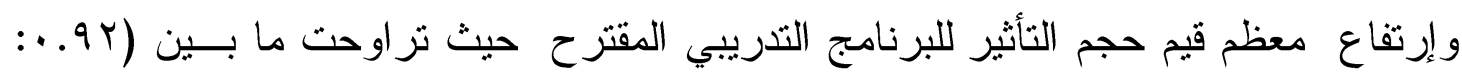
1. الإحصائية الخاصة بالمتغير ات الكينماتيكية لخطوة الحاجز الثانى لدى عينة الدر اسة الأساسية

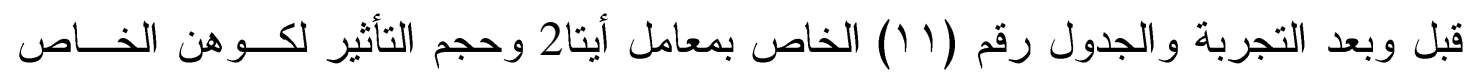


بجميع المتغير ات الكينماتيكية لخطوة الحاجز الثانى قيد الدراسة للمجموعة التجريبية قبل وبعد

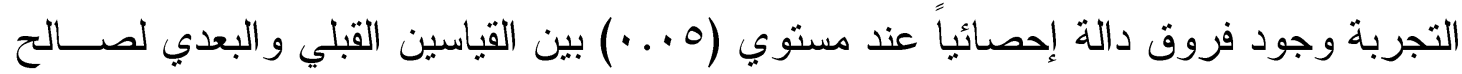

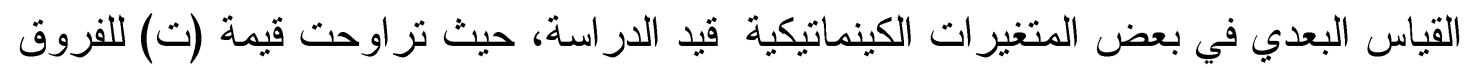

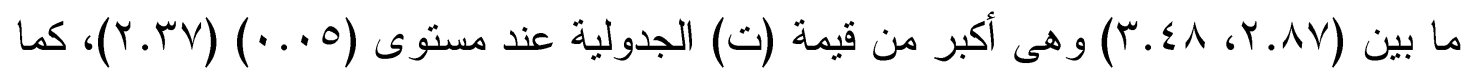

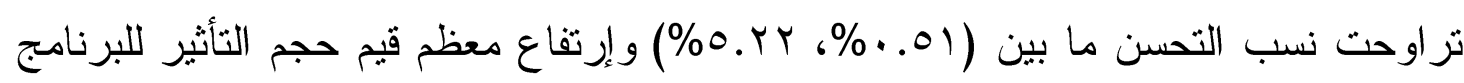

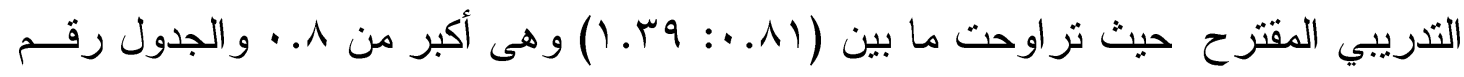

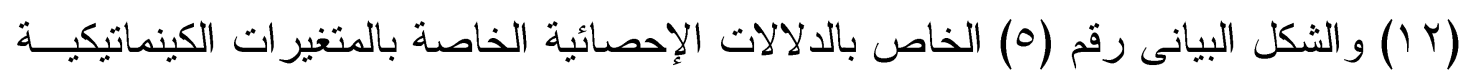

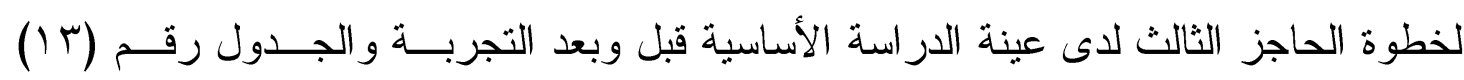

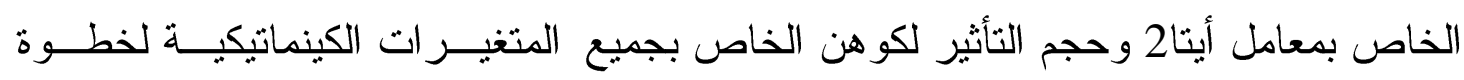

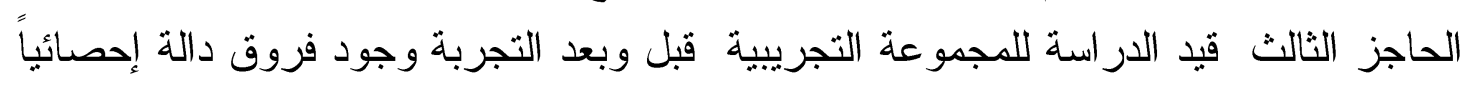
عند مستوي (0. . ·) بين القياسين القبلي و البعدي لصالح القياس البعدي في معظم المتغيرات

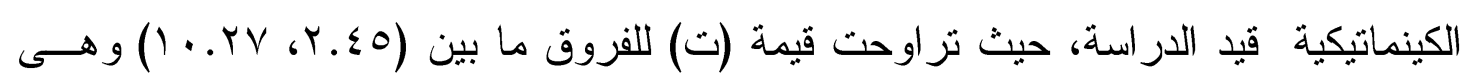

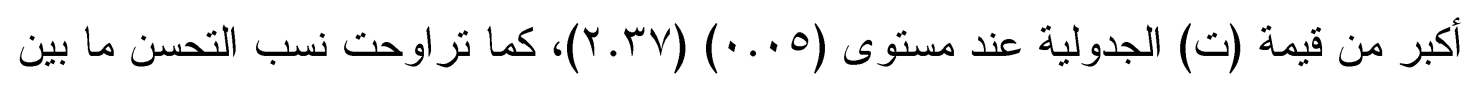

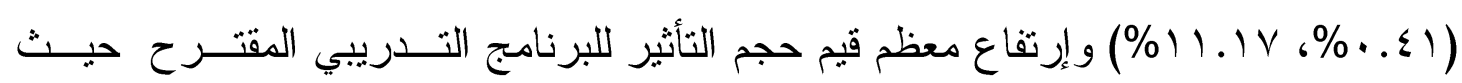

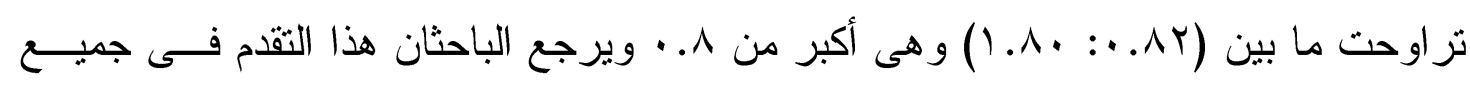

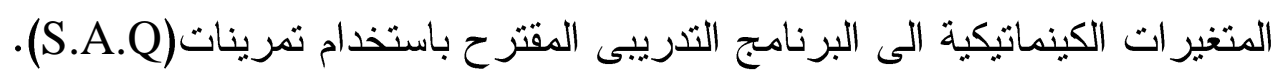

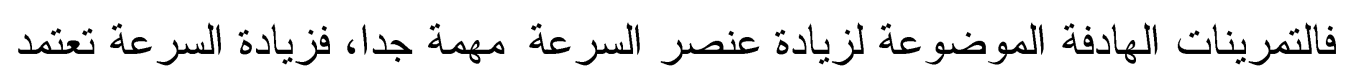

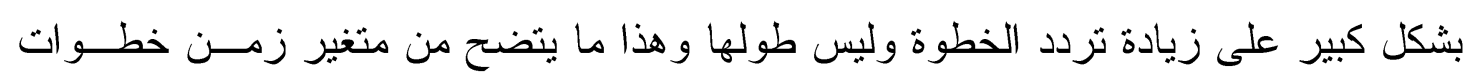

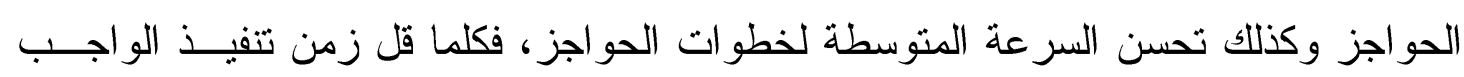

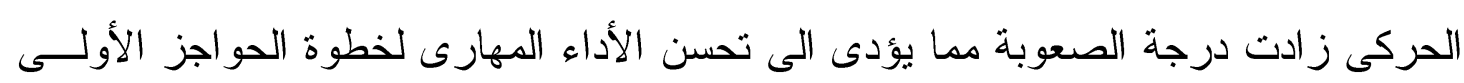

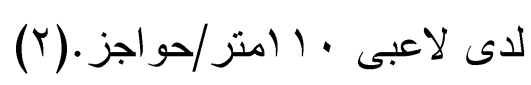

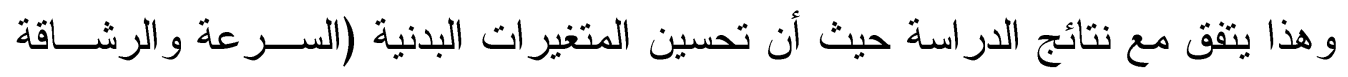
و القوة) و التى ترتبط بطبيعة الأداء المهارى و التى تحسنت نتيجة لإستخدام تمرينات (S.A.Q)

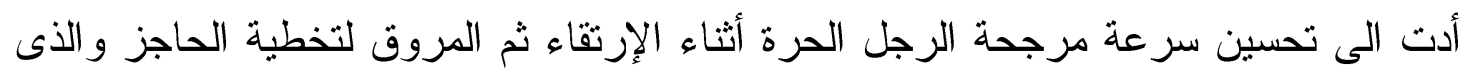

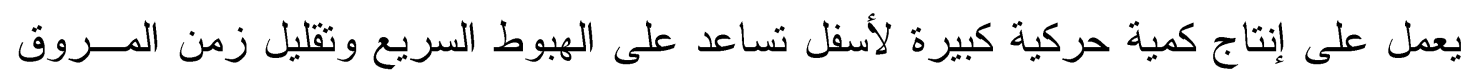

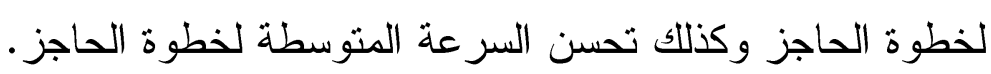

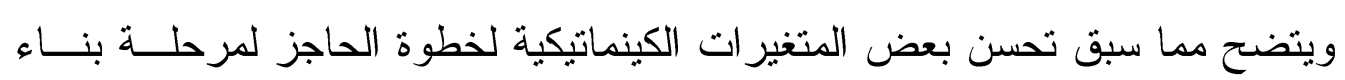

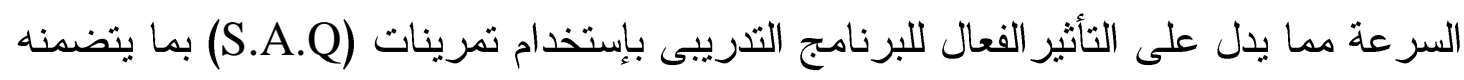

\section{مجلة أسيوط لعلوم وفنـوز التربية الرياضية}




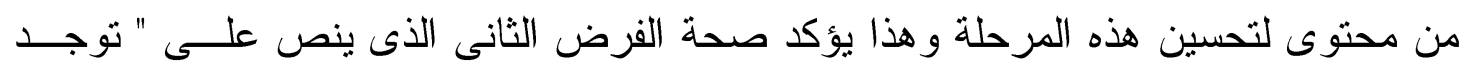
فروق ذات دالة إحصائية بين القياس القبلى و البعدى للمجموعة التجريبية فى بعض المتغيرات

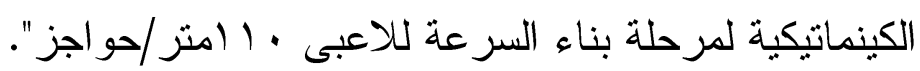

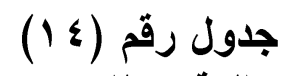

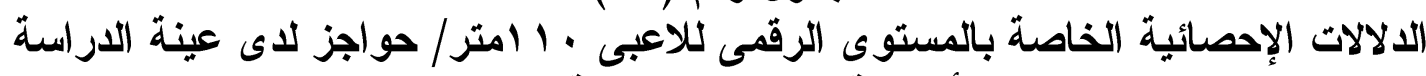

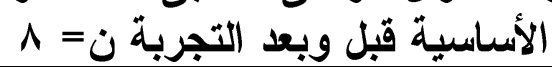

\begin{tabular}{|c|c|c|c|c|c|c|c|c|c|c|}
\hline \multirow{2}{*}{ 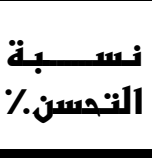 } & \multirow{2}{*}{ الدسالةوك } & \multirow{2}{*}{ 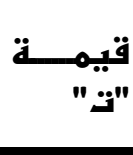 } & \multicolumn{2}{|c|}{ 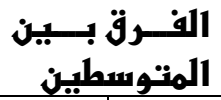 } & \multicolumn{2}{|c|}{ القياسر البعدي } & \multicolumn{2}{|c|}{ القباس القبلي } & \multirow{2}{*}{ والقياســـ } & \multirow{2}{*}{ 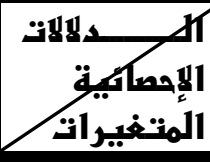 } \\
\hline & & & $\varepsilon \pm$ & سَ & $\varepsilon \pm$ & سَ & $\varepsilon \pm$ & سَ سَ & & \\
\hline$\% 3.02$ & 0.00 & *12.28 & 0.11 & 0.49 & 0.73 & 15.86 & 0.70 & 16.35 & (ث) & 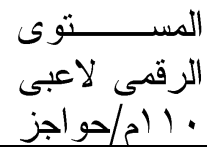 \\
\hline
\end{tabular}

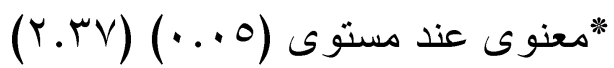

يتضح من الجدول رقم (ع ()) و الثكل البيانى رقم (T) الخاص بالدلالات الإحصــائية

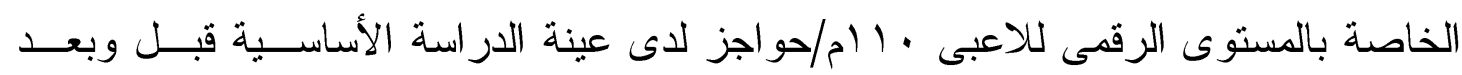
التجربة وجود فروق دالة إحصائياً عند مستوي (0.05) بين القياسين القبلي و البعدي لصــالح

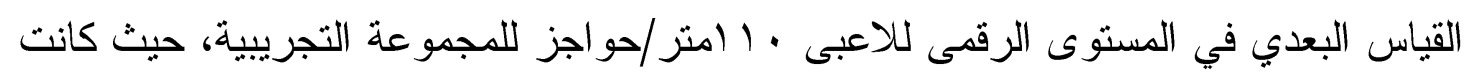

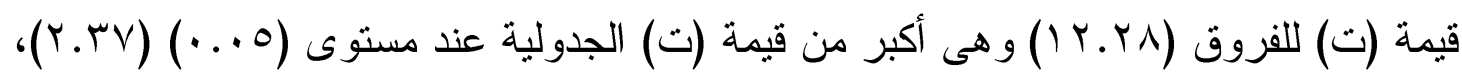

$$
\text { جدول رقم (10) }
$$

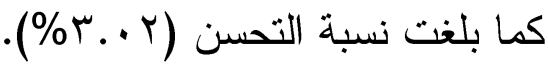

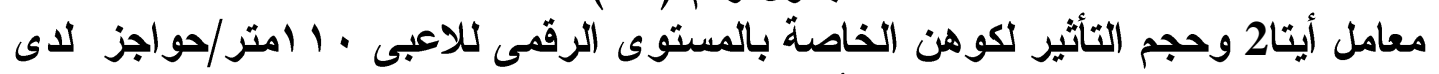

\begin{tabular}{|c|c|c|c|c|c|c|}
\hline التنأثئر & الكوهنير & إيتامال & الدلانتوى & "تيمة" & واقياسة & آلدالالنتالالهمائية \\
\hline متوسط &. $\mathrm{TV}$ & .99 & $\ldots$ & IY.YA & (ث) & 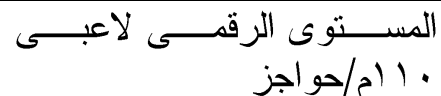 \\
\hline
\end{tabular}

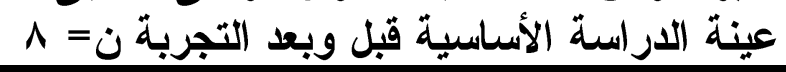

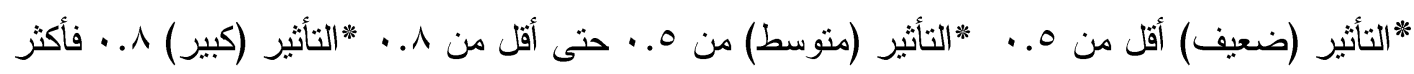

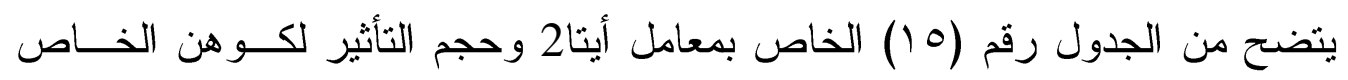
بالمستوى الرقمى للاعبى • ( امتر/حو اجز للمجموعة التجريبية قبل وبعد التجربة، حيث كان

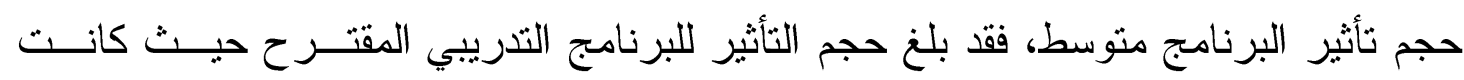

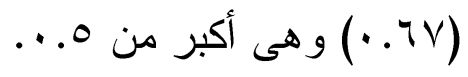




\section{Y^ฯ}

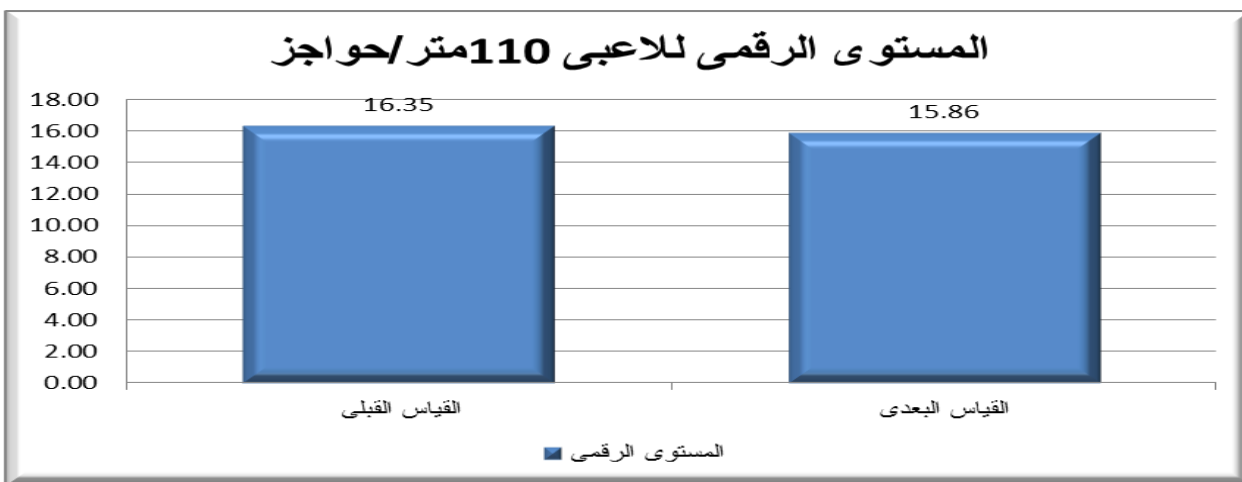

الثكل البيانى رقم (†) الخاص بالمتوسطات الحسابية للمجموعة التجريبية للمستوى الرقىى

\section{للاعبى · ل1 امتر/حواجز قبل وبعد التجربة}

يتضح من الجدول رقم (ع () و الثكل البيانى رقم (؟) الخاص بالدلالات الإحصـــائية

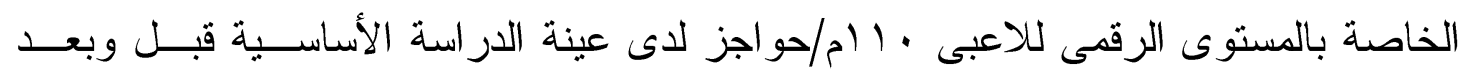

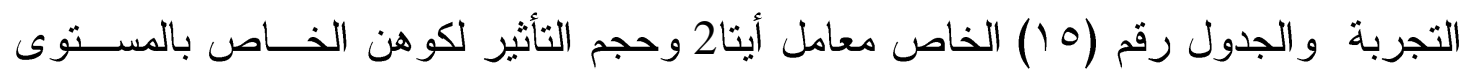

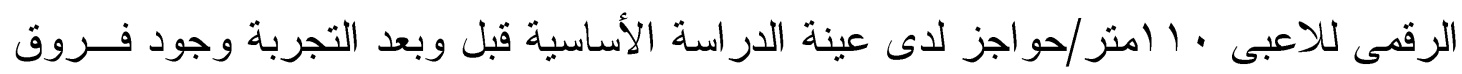

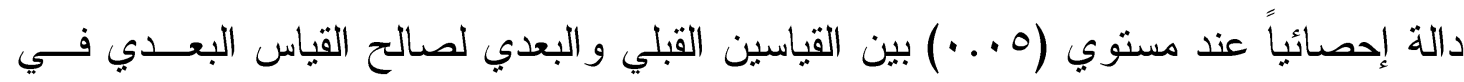

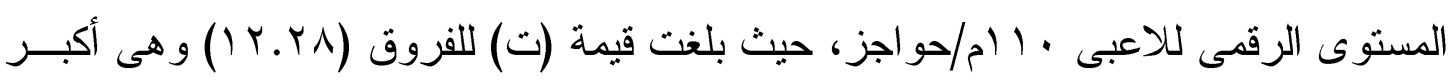

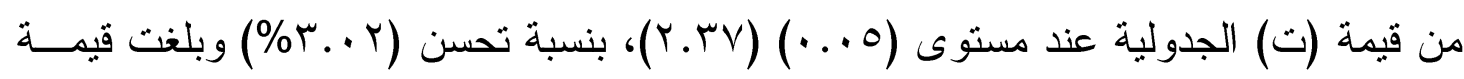

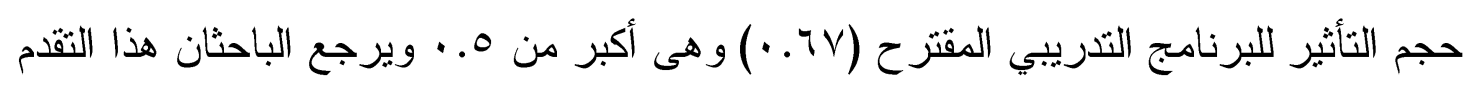

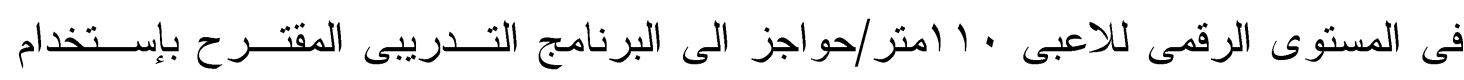

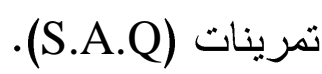

ويؤكد الكثير من المراجع على أن التمرينات البدنية المبنية على أسس علمية تعهـل

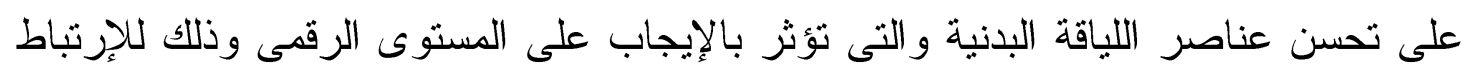

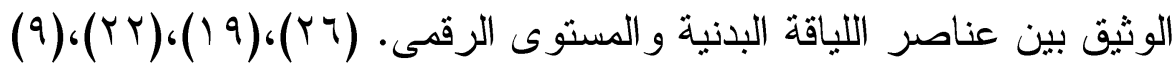

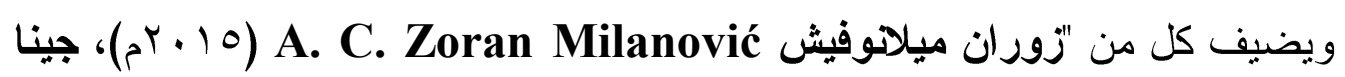

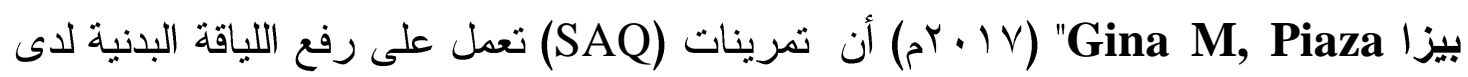

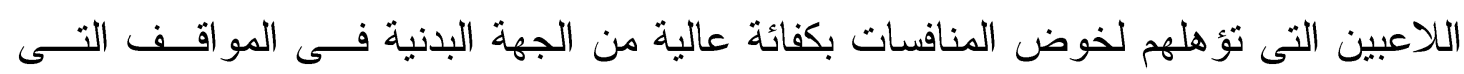

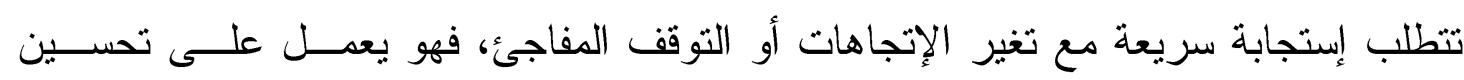

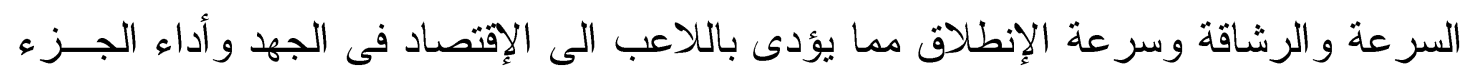


المهارى بشكل أفضل، مما يؤثر بالإيجاب على المستوى الرقمى للاعبى • ل (امتر/حــواجز. $(r \cdot: r)(1 \cdot 1: r \cdot)$

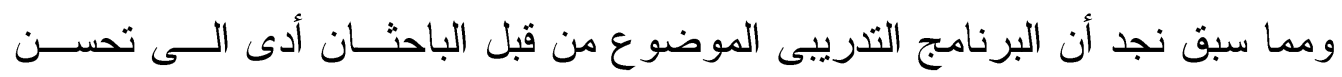

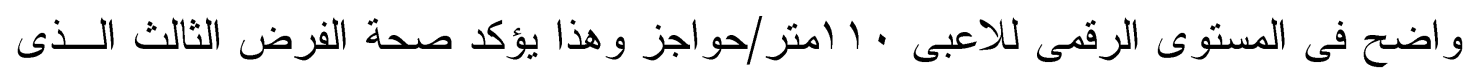

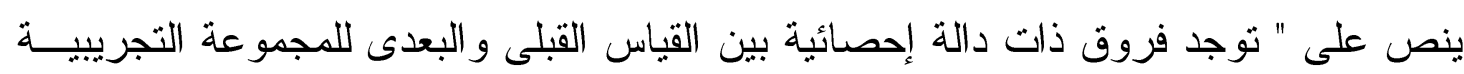

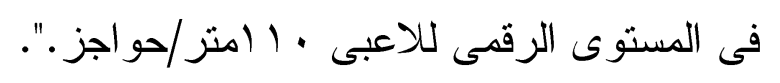
الإستنتاجات:

ا- البرنامج التدريبى المقترح بإستخدام تمرينات S.A.Q أدى إلى تحسين المتغيرات البدنية

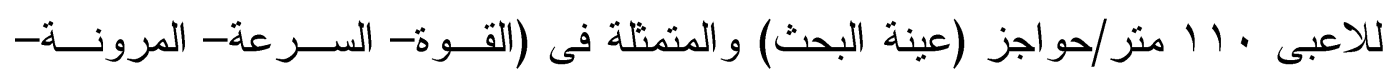
الرشاقة).

Y- البرنامج التدريبى المقترح بإستخدام تمرينات S.A.Q أدى إلى تحسين بعض المتغيرات

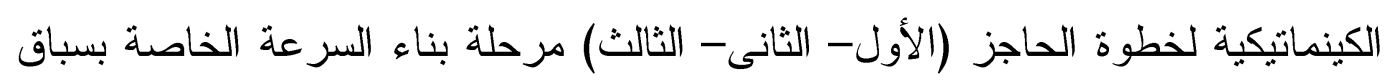

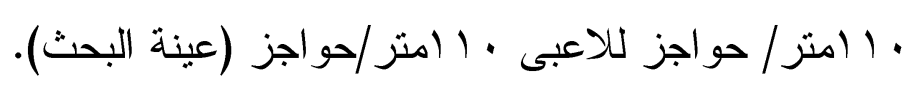

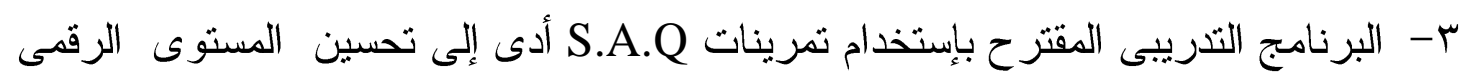
للاعبى · (امتر/حواجز (عينة البحث). التوصيات: 1- إستخدام البرنامج التثريبى المقتر ح و الخاص بتمرينات (S.A.Q) للمساهمة فى تحسـين

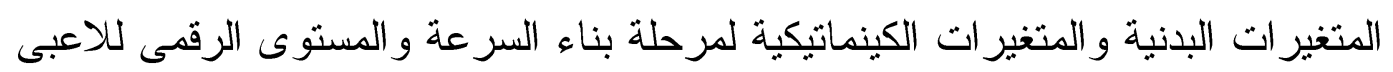

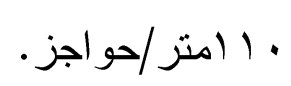

ץ- إجر اء در اسات مماتلة على مهار ات أخرى ومر احل عمرية مختلفة للاعبـى مســابقات

$$
\text { الميدان و المضمار بإستخدام تمرينات (S.A.Q). }
$$

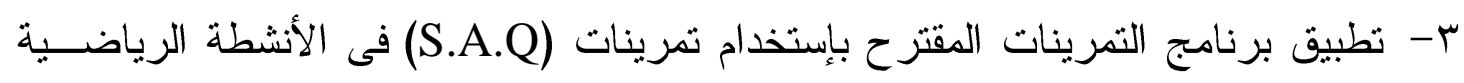

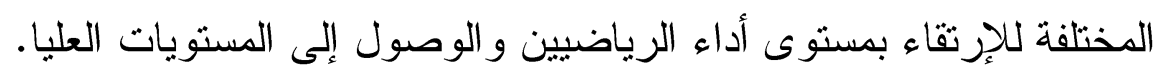

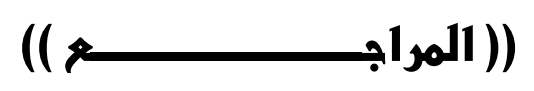

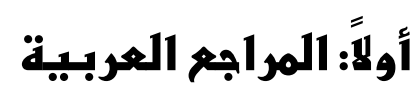

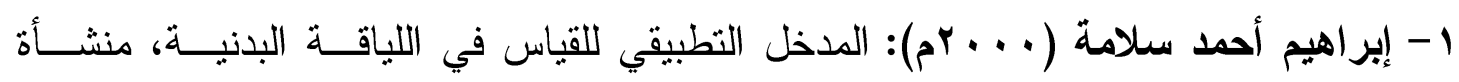

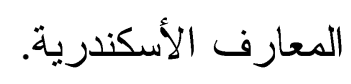




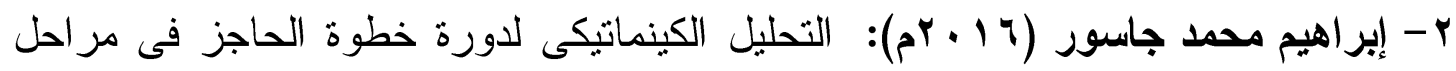

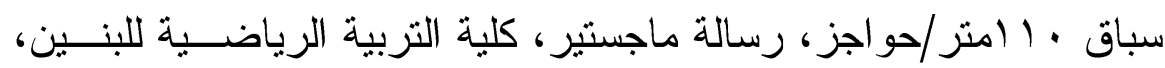
جامعة الإسكندرية.

r- أبو العلا أحمد عبد الفتاح (r ا + rم): التدريب الرياضى المعاصر ، الطبعة الأولــى، دار الفكر العربى، القاهرة.

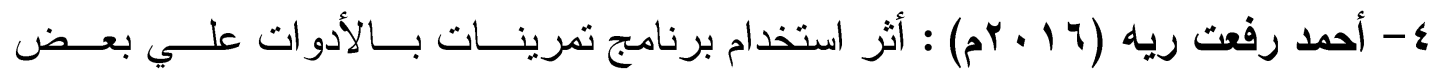

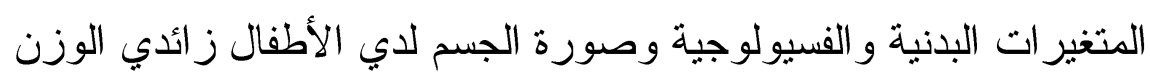

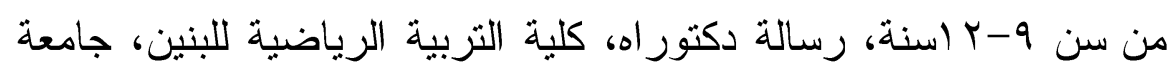
الاسكندرية.

ه- أسامة إسماعيل الثاعر (11 + rم) : تأثير بعض المتغيرات الكينماتيكية لخطوة الحاجز

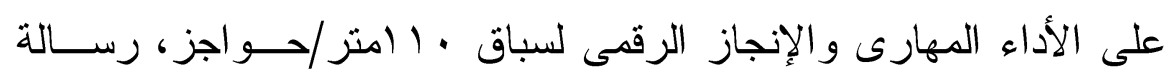

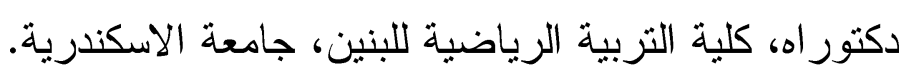

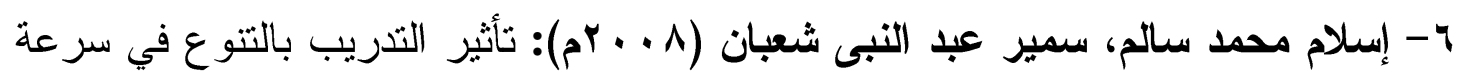

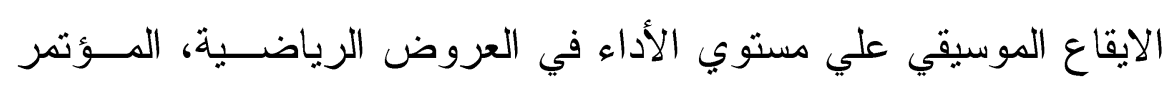

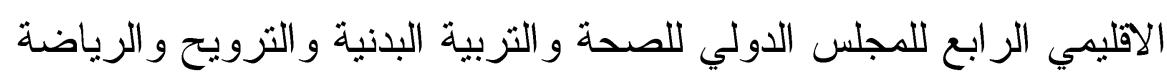

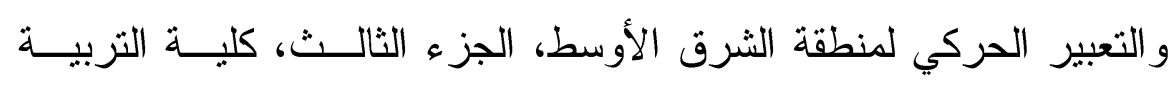

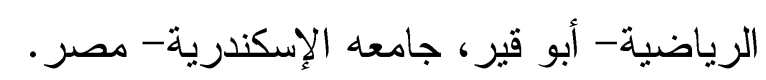

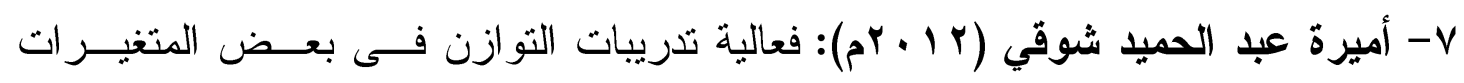

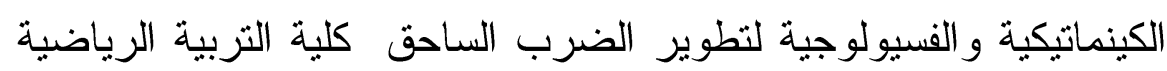
للبنات، جامعة الإسكندرية. 1- زكى محمد حسن (10 • بم): أسلوب تدريب S.A.Q أحد الأساليب التـدريب الحديثـة (السرعة و الرشاقة وسرعة الإنطلاق)، الطبعة الأولى، دار الكتاب الحبل الحديث.

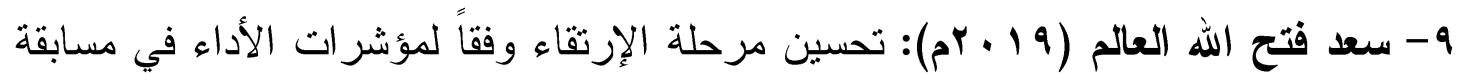

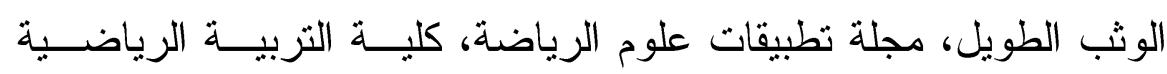

$$
\text { للبنين، جامعة الإسكندرية. }
$$

• 1 - السعيد محمد أبوبكر(r 1 rم): تأثثر التمرينات الهو ائية و اللاهو ائية بالحبل على الحالة

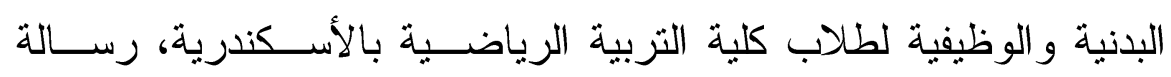
ماجستير، كلية التربية الرياضية للبنين، جامعة الاسكندرية. 


\section{ห^q}

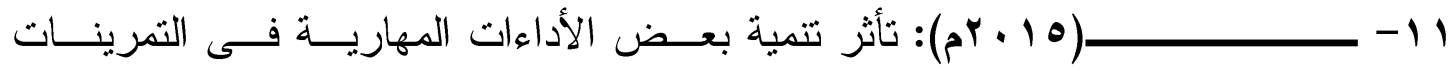

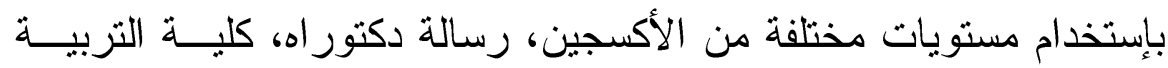
الرياضية للبنين، جامعة الاسكندرية.

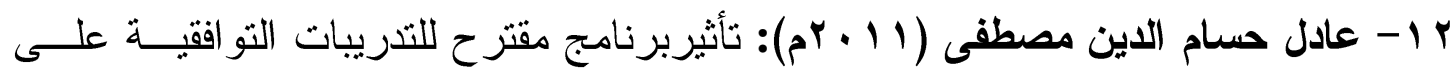

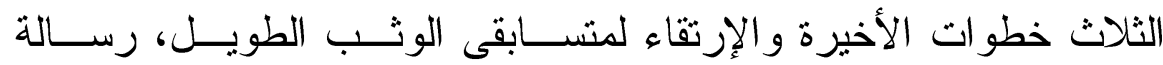
ماجستير، كلية التربية الرياضية بنين، جامعة الأسكندرية.

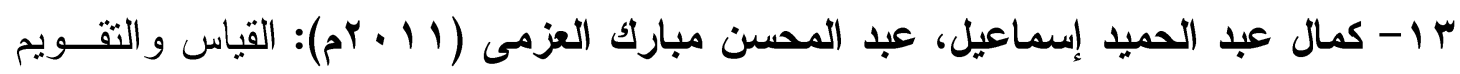
في التربية الرياضية المدرسية، الطبعة الأولى، دار الفكر العربى، القبل، القاهرة.

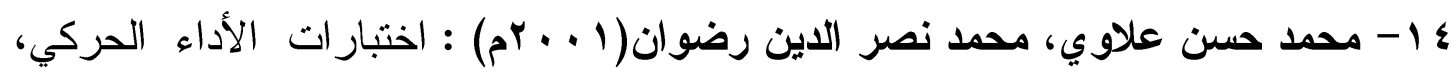
ط با، دار الفكر العربي، القاهرة. ه 1 - محمد صبحى حسانين ( . . rم): القباس و التقويم في التربية البدنية و الرياضية الجزء

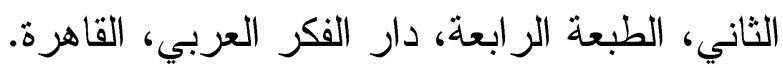
17 - 17 الأول، الطبعة السادة، دار الفكر العربى، القاهرة.

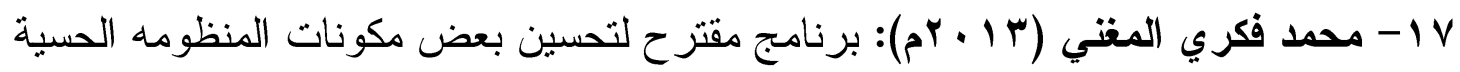

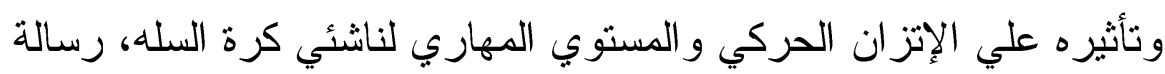
ماجستسر، كلية التربية الرياضية، جامعة كفر الثيخ.

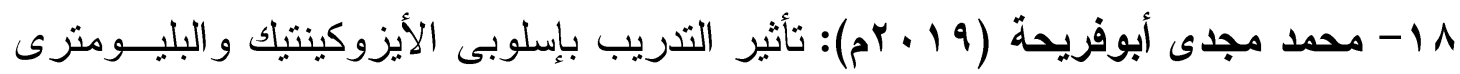

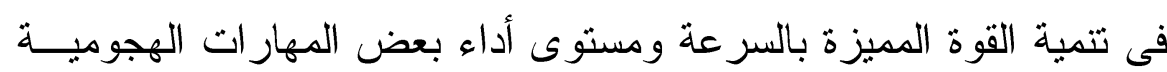

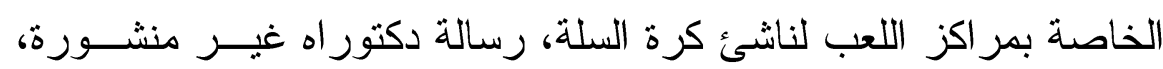
كلية التزبية الرياضية، جامعة طنطا.

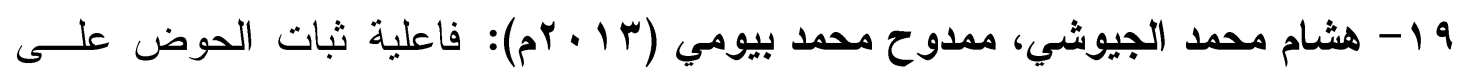

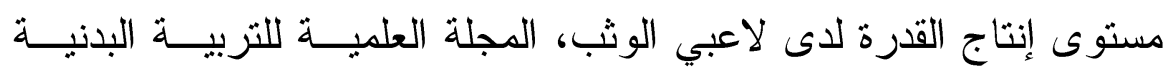
و علوم الرياضة، كلية التربية الرياضية للبنين، جامعة حلو لاعبان. ثانباً: المراجم الأجنببية وعم المباض

20- A.C.Zoran Milanovic (2015): Does SAQtraining improve the speed and flexibility of young soccer players? A randomized 
rq.

controlled trial Ethics Committee of Faculty of kinesiology, University of Zegreb.

21- Gina M, Piaza (2017): ABCfitness training specialist supplemental section.

22- Kwang Jan Kim (2015): Effects of Center Muscles Strengthening Training on flexibility, Muscular Strength and Driver Shot Performance in Female Professional Golfers, Korea institute of sport science, international journal, vole 22

23- Manoj Singh rana, Yajuvendra singh rajpoot (2015): Relationship of Coordinative Abilities to Playing Ability in Combative Sports, IOSR Journal of Sports and Physical Education

24- McDermott, Shane (2016): effects of plymetric,SAQ and traditional training on sprint, agility, jumping passing and shooting performance in young soccer players, Department of physical Activity, University of Jyvaskyla, Master's Thesis in Science of Sports Coaching and Fitness Testing, 57pp.

25- Nageswaran, $\mathbf{A}(\mathbf{2 0 1 3})$ : effect of SAQ training on speed agility and Balance Among Inter collegiate Athletes IJSRInternational journal of scientific research.

26- Sukalinggam,C et all (2012): Stability Ball Training on Lower Back Strength Has Greater Effect in Untrained Female Compared to Male, Journal of Human Kinetics. 